Article

\title{
Co-Housing Response to Social Isolation of COVID-19 Outbreak, with a Focus on Gender Implications
}

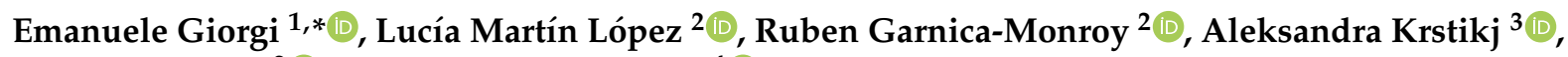 \\ Carlos Cobreros $^{2}$ (D) and Miguel A. Montoya ${ }^{4}$ (D) \\ 1 Tecnologico de Monterrey, Escuela de Arquitectura, Arte y Diseño, Campus Chihuahua, \\ Chihuahua 31300, Mexico \\ 2 Tecnologico de Monterrey, Escuela de Arquitectura, Arte y Diseño, Campus Querétaro, Santiago de Querétaro \\ 76130, Mexico; luciamartinlopez@tec.mx (L.M.L.); rumonroy@tec.mx (R.G.-M.); ccobreros@tec.mx (C.C.) \\ 3 Tecnologico de Monterrey, Escuela de Arquitectura, Arte y Diseño, Campus Estado de Mexico, \\ Cd López Mateos 52926, Mexico; sandra.krstik@tec.mx \\ 4 Tecnologico de Monterrey, Escuela de Arquitectura, Arte y Diseño, Campus Guadalajara, \\ Guadalajara 45019, Mexico; mmontoya@tec.mx \\ * Correspondence: egiorgi@tec.mx
}

check for updates

Citation: Giorgi, E.; Martín López, L.; Garnica-Monroy, R.; Krstikj, A.;

Cobreros, C.; Montoya, M.A.

Co-Housing Response to Social Isolation of COVID-19 Outbreak, with a Focus on Gender Implications. Sustainability 2021, 13, 7203. https:// doi.org/10.3390/su13137203

Academic Editors: Belinda Lopez-Mesa and Enrique Cano-Suñén

Received: 17 May 2021

Accepted: 23 June 2021

Published: 27 June 2021

Publisher's Note: MDPI stays neutral with regard to jurisdictional claims in published maps and institutional affiliations.

Copyright: (C) 2021 by the authors Licensee MDPI, Basel, Switzerland. This article is an open access article distributed under the terms and conditions of the Creative Commons Attribution (CC BY) license (https:// creativecommons.org/licenses/by/ $4.0 /)$.

\begin{abstract}
COVID-19 forced billions of people to restructure their daily lives and social habits. Several research projects have focused on social impacts, approaching the phenomenon on the basis of different issues and scales. This work studies the changes in social relations within the well-defined urban-territorial elements of co-housing communities. The peculiarity of this research lies in the essence of these communities, which base their existence on the spirit of sharing spaces and activities. As social distancing represented the only effective way to control the outbreak, the research studied how the rules of social distancing impacted these communities. For this reason, a questionnaire was sent to 60 communities asking them to highlight the changes that the emergency imposed on the members in their daily life and in the organization of common activities and spaces. A total of 147 responses were received and some relevant design considerations emerged: (1) the importance of feeling part of a "safe" community, with members who were known and deemed reliable, when facing a health emergency; and (2) the importance of open spaces to carry out shared activities. Overall, living in co-housing communities was evaluated as an "extremely positive circumstance" despite the fact that the emergency worsened socialization.
\end{abstract}

Keywords: co-housing; social isolation; COVID-19; coronavirus; community; survey

\section{Introduction}

During the early period of the COVID-19 outbreak, social distancing was the only effective strategy to limit the number of infections and, consequently, hospitalizations and deaths, due to the new coronavirus. Social distancing had varied consequences at the global and local levels. In addition to the economic impacts, daily life underwent enormous upheavals: from work and school activities, social relations, to the use of public and private urban services. These changes provoked a profound reconsideration of our way of life in all fields of knowledge. In particular, many concerns have emerged regarding domestic and urban spaces. This article describes the research carried out to understand how cohousing communities, which are based on mutual sharing, reacted to the requirement of social distancing.

\subsection{COVID-19 Outbreak}

On 7 January 2020, the Chinese authorities identified a deadly new strain of coronavirus, named SARS-CoV-2. On March 11th, the WHO announced the novel coronavirus disease to be a global health crisis. The COVID-19 crisis, which reached the level of a 
pandemic, has been described as the "greatest challenge that humankind has faced since the 2nd World War" [1]. The subsequent national and local measures taken to slow down transmission and prevent saturation of the healthcare system put the entire world in "lockdown" mode, which had significant implications on how people communicate, work, study, and occupy habitats. Industries were closed down and public transit was put on hold while private homes became offices and schools. The unprecedented shift in mobility and daily behavior, which left megacities such as New York, Berlin, and Beijing desolated and quiet, is nevertheless also an opportunity to re-evaluate the way people live and share common goods.

Experiences of managing the COVID-19 crisis revealed the complexity of habitability in cities and their peripheries, conditioned to some degree by equity and access to public services. This has triggered a discussion around how urban resilience is conceptualized, especially considering the capacity of an urban system to adapt, collectively imagine a better future and evolve, when faced with a crisis. Scientific articles related to the COVID19 disease have been numerous, addressing global awareness (primarily at national levels) and covering a wide range of disciplines, including economy, mathematics, and social sciences [2-5]. The effects of social isolation on physical and mental health have also received a great deal of attention in scientific literature [6-9]. In architecture and planning, the main challenges involve the rethinking of cities in terms of urban health improvements, as well as mobility patterns and land-use changes that could support such significant shifts in behaviors and daily functions. Nevertheless, there was a significant lack of design proposals for strategies and actions during the first period of the contingency [10]. For a deeper focus on the literature review, a table on current published research is included in Appendix A.

The pandemic has reinforced some of the most characteristic features of cities: the closeness and physical coexistence between people in the urban space, the lack of public services and minimal housing conditions, and the lack of access to urban public services such as parks, green areas, and public gardens in popular neighborhoods, to name a few. Today, the domestic space, 'the dwelling', takes on a new role in which a set of problems associated with precarious services become evident. The suitability of housing to support life for several weeks without social contacts, and in some areas without even basic services such as clean water required for sanitation and cooking, access to the internet, a space for working or learning, and personal needs of each family member, puts housing at the center of designers' and policy makers' responsibilities. Moreover, the need for accompanying services close to homes to meet various needs in a controlled way, such as open-air spaces for sports and mental distraction that domestic spaces in themselves cannot provide, is being recognized [11,12]. The disruption of the traditional function of both domestic and public spaces caused by the pandemic calls for an urgent re-assessment of the typology of housing to set a basis for urban policy aimed at improving urban health and community resilience.

\subsection{Social Distancing}

The abrupt appearance of COVID-19 and it subsequently being declared a pandemic, led the governments of the world to ask, demand, or force their citizens to maintain social distancing to slow down the spread of the virus. Governments, scientists, and specialists proposed protocols, such as self-isolation, social distancing, quarantine and complete lockdown [13], prohibition of any nonessential public gatherings, closure of educational, public and cultural institutions, ordering people to stay home apart from exercise and essential tasks [14], border closures, travel restrictions, and business closures, all of which have caused interruptions in daily activities, as well as unemployment [13]. The logic behind these measures was that, by reducing physical interaction between people, the disease would spread more slowly [15-18], which would reduce the saturation of the overworked emergency services, hospitals and health personnel, as well as gaining time to develop a vaccine or better palliative and treatment protocols for the disease. 
Social distancing has economic costs due to the slowdown in activities; its impact has been calculated at between 4 and 5 points of global GDP [16]. A positive relationship has been found between social distancing (due to a restriction of business activities) and a decrease in the rate of COVID-19 infection [3]. Recent publications show that these measures have had economic benefits. Greenstone and Nigam [19] found that these benefits could amount to a saving of about $\$ 8$ trillion dollars for the U.S. alone, while social distancing between March and October 2020 would save 1.7 million American lives.

There is a link between poverty and disease susceptibility in the Global South. In addition, maintaining social distance and preventive hygiene is not feasible for the entire population, especially for those living in crowded conditions; sharing water and sanitation services, depending on overwhelmed public health services and public transport, and with limited access to communication tools [2]. Social isolation has posed a serious threat to physical and mental health $[6,15]$. It has led to greater loneliness among people who already lived alone, which fueled anxiety, suffered by both people infected by COVID-19 and non-infected people [20]. In some cases, social distancing aggravated other problems related to stress, such as depression, cardiovascular diseases, and sleep problems [21], causing a decrease in well-being [22] as well as alterations in the self-regulation of behavior, cognitions, and emotions [23]. The COVID-19 stress syndrome is conceptualized as a multifaceted construct that includes disease-related fears, compulsive control, and symptoms of traumatic stress (TS) [24-26] that was moderately experienced by a large part of the population [24], even among relatively low-risk populations not directly affected by COVID-19 [27]. These symptoms are found particularly in those more directly exposed to COVID-19 [15,25].

The current pandemic has resulted in a generalized sense of vulnerability [13], which can motivate self-protective behavior [26], undermine sense of security, increase concerns, and trigger TS reactions [23,25]; thus, causing greater sensitivity to signs of the disease, interpersonal avoidance, and cognitive biases or extreme attitudes that can reduce affiliation with others [27], and reduce social connection [15]. There is a risk of post-traumatic stress disorder (PTSD), already observed after traumatic events [28], such as psychological and physiological reactions to stress in threatening situations. Women [29] and people with a history of mental health disorders [30] are at higher risk. Confinement puts domestic coexistence at risk [31], with evidence of increasing domestic violence as households face longer periods of lockdown and financial stress [32], which may peak in times of stress [33]. Emotional affectations and psychological discomfort are detected, affected by quarantine duration [7], symptoms of acute and post-traumatic stress [34], anger [35], fear, sadness, disgust, and uncertainty. There is also evidence of emotional contagions [36], as well as increased alcohol consumption and drug abuse [8], anxiety and insomnia [37], self-medication, increased suicidal ideation, and behavior among at-risk populations [8].

Younger adults and women have reported more distress and TS after the COVID-19 outbreak than older adults and men [15]. There were cases of increased prevalence of depression, insomnia, post-traumatic stress disorder, feelings of anger and frustration [9], and anxiety [38] with greater affectation in women [39], especially pregnant women. There was also a significant decrease in the quality of life of those who showed high levels of stress and concern due to changes in lifestyle and decreased levels of physical and outdoor activity [40], which was fundamental for them [41]. The symptoms of COVID-19 in children are milder than in adults; children have a better prognosis and deaths are extremely rare, but isolation has entailed substantial risk and affectation [42] with consequences in terms of health, safety, and well-being [43]. There is a prevalence of anxiety among children with parents who have essential jobs and also with social distancing, whether without parents or with parents with a lower or younger educational level [43]. It is important that children maintain quality educational opportunities [14] and have access to their peers to maintain social and cognitive development [43]. Furthermore, there has been an increase in physical, emotional, and sexual violence against children during the COVID-19 pandemic [44]. The psychological impact on university students has also been studied, 
with cases of anxiety [45], dysfunctional domains of personality, negative activity and detachment, emotional problems [46], with more negative feelings such as worry, anger, guilt, nervousness, and sadness [47], as well as intense concern about the acquisition of information from social networks [48].

Emotions, contagious in social networks [49], can create climates of opinion through mass and interpersonal communication. Confidence in digital ecosystems is denoted to disseminate and share official and unofficial information [36], which has brought opportunities and challenges for communication, compared with traditional media [50]. Interdisciplinary proactive measures, international solidarity and collaboration, and a global perspective is necessary. Social connection and adaptive regulation of worries can help reduce TS [13]. COVID-19 can also increase our capacity for solidarity [51] and mutual care during, and possibly beyond, the pandemic [52].

\subsection{Co-Housing}

Co-housing is a housing solution that has been very successful in recent decades and is continuing to gain increasing attention from the market, construction companies, and associations focused on the housing phenomenon. Co-housing is a form of contractual community (Brunetta, Moroni) [53] and intentional community (Guidotti) [54] that bases its ethos on the willingness of its members to participate in a housing project in which several spaces, services, and activities are intentionally shared to develop relationships and social interaction which, according to the residents, improves the quality of life [55]. Co-housing, beyond being very interesting because it highlights the need to think of contemporary design solutions capable of supporting a return to a social dimension of living, proves to be a housing solution with many implications for design activity, the housing market, legislation, and urban phenomena more generally [56,57].

One of the main characteristics of co-housing communities, as implied by the name, is the sharing of spaces and activities. While sharing remains one of the fundamental aspects of life in such communities, the level of sharing can greatly vary according to the type of co-housing and the choices made by a community at the beginning of the experience. This aspect, together with the different contexts into which the project is inserted, the different motivations that drive the creation of a community, or the different social compositions, contributes to making co-housing experiences extremely varied and easily adaptable to different needs and contexts.

With these characteristics, co-housing is a successful solution for people who are looking for a lifestyle focused on enhancing the social environment. Furthermore, in the last decade, the focus on this housing solution has been moved forward by groups of elderly people who see living in a socially active environment as an important opportunity to mutually support one another in facing the challenges of old age [58].

Moreover, co-housing communities have also been studied with a focus on gender equality and use of spaces. Vestbro and Horelli show how the aim of gender equality has been significant in all the historical models of shared-living experiences and in contemporary co-housing in particular, promoting collaboration and a sharing of responsibilities among all the community members [59]. Furthermore, Zaida Muxí underlines how cohousing communities facilitate the ability to overcome certain spatial patterns of gender, and how they become an "essential tool in the emancipation of women" [60].

The phenomenon of co-housing is therefore a housing trend that has at the basis of its existence, the sharing of spaces and activities among the members of the community; an aspect that undoubtedly had to be reconsidered in some way due to the pandemic situation of COVID-19. 


\subsection{Housing, Open-Air Spaces and the COVID-19 Outbreak: State of the Art and the Research Question}

\subsubsection{Open-Air Spaces}

The behavior of individuals and the environment are related [61-63], with nature having an effect on human health [61]. Interacting with natural environments [63] or simply looking at them can reduce stress, with benefits for individual well-being. There is strong scientific evidence that outdoor experiences (OE), contact and visualization of natural beauty, provide personal physiological $[61,62,64]$, physical and mental [65], spiritual [66], and social (empathy, generosity, trust, and collaboration) benefits [67], especially for children and adolescents [68]. During confinement, contact with OE and nature has been reduced to the detriment of the well-being of the population, and our health is directly related to our closeness with nature. Views to the outdoors, having access to exterior landscapes [69-71], allowing in natural light [72], nature patterns, biomimicry, space diversity, native elements, plants, plant patterns, simulation of natural features or water [71], constitute restorative healthy environments [72].

\subsubsection{Housing}

The physical characteristics and architectural patterns of the built environment are directly associated with health $[73,74]$. Housing is a key area through which COVID-19 is experienced [75]. In confinement, houses became the only place to sleep, eat, work, practice sports, and socialize [76], accelerating morphological changes [77]. Overcrowding and poor housing conditions are associated with the spread of respiratory diseases, such as tuberculosis, influenza, and COVID-19 [78,79], and leads to an increased risk of depressive symptoms during confinement [63]. In the informal settlements in the Global South, where more than one billion people are living, social distancing and quarantine are almost impossible [80] and it is more complex to address the impact of COVID-19 [52]. Housing policy plays a fundamental role in this health crisis [52]. An interdisciplinary approach involving urban planning, public and environmental mental health, epidemiology, and sociology is needed to investigate the effects of the built environment on the mental health and well-being of the population [81], especially in times of COVID-19 [82].

\subsection{Research Question}

Analyzed texts that deal with the issue of COVID-19, related to community engagement, mutual support, meaningful social connections, and the social fabric of the neighborhood focus on the study of how to improve the quality of life of the inhabitants when they started spending more time in their own homes. Nevertheless, urban-architectural elements that facilitate their life are not specified. As can be extensively perceived from the academic literature review, understanding how organized groups of people, who are used to sharing spaces and activities on a daily basis, face social isolation imposed in order to limit COVID-19 spread, is very relevant. These two aspects still need to be understood: (1) how the co-housing communities experienced isolation; and (2) which urban-architectural elements contributed to this type of life. Studying the implications of sharing limitations in co-housing can bring important considerations in terms of architectural design and social involvement in housing. Therefore, the research question is: How have co-housing communities reacted to social isolation, focusing in particular on social interaction and the role of spatial solutions?

\section{Materials and Methods}

To answer this research question, the authors decided to submit a questionnaire to various co-housing communities, so as to receive opinions about their experience during isolation. The method chosen for data collection for correlational research was a survey questionnaire. The choice of the survey by means of a questionnaire is because this research method, perhaps the most popular for the correlational research design, enables the researchers to cover an extensive amount of information [83]. Therefore, to carry out 
this activity: (1) a questionnaire was structured; and (2) the communities to be invited to take part in the activity were chosen.

\subsection{Survey Design}

In the design of the survey questionnaire, the authors followed the suggestions and considerations proposed by Groat, who adapted these from Research Methods in Education and Psychology [84].

Firstly, the main objectives and themes to be covered were defined. Thus, considering: (1) the vast panorama of types of co-housing; and (2) the various facets of meaning that "reacting to social isolation" can refer to, the research focused on only some aspects. A first series of questions concerned some characteristics of the community and of the person, while a second series of questions concerned aspects of social interaction inside and outside the community. A final series of questions concerned some spatial devices and the role they played in varying social interactions and how they eventually changed. The questionnaire had three main sections, requesting information about:

- Baseline characteristics: referring to baseline characteristics of the participants (age and gender) and of their own community (name, country, region, dimension, and context). These questions had the goal of understanding the distribution of the population taking part in the survey and to draw people to the questionnaire.

- Social interaction: questions to describe the variation in social interaction, comparing pre-COVID-19 and COVID-19 periods, with particular emphasis on the variation of relations within and outside the community.

- Spatial considerations: questions to describe the variation in the role that private, shared, and open-air spaces have in co-housing community life.

Subsequently, the response formats were defined, opting, in the case of responses to social interaction and spatial considerations, for responses on a closed scale of 10 points. The questions were therefore defined, following these precautions: use of short and positive sentences (avoiding "not", "never", etc.), with only one question and with concepts that would be very clear and easy to understand.

The order of the questions was also organized, so as to follow the main themes previously defined and to have easier questions at the beginning. To facilitate the understanding of a question that the authors assessed as difficult to understand for a "non-specialized public" (the definition of the community's context), it was decided to adopt a graphic support. Finally, the authors wrote a short presentation of the research and its objectives, presented a guide for the responses to the questions, and invited participants to respond only and exclusively if they consented to participate in the research.

\subsection{Co-Housing Communities: Definition and Selection}

Non-probability sampling, based on the researchers' previous works and subjective judgments, was used to build a representative sample. A total of 60 co-housing communities were then selected and chosen on the basis of these two aspects: (1) the Englishspeaking communities that already took part in previous research activities, collected in the book The Co-Housing Phenomenon (in Canada, United States, UK, Spain, Australia and New Zealand) [53]; and, to enrich the sample, (2) the co-housing communities present on the web page "Cohousing.org", which gathers intentional communities from the United States [85].

To use a questionnaire in a single language, with the goal of avoiding problems related to the translation or to the understanding of the questions, the authors decided to prepare a questionnaire in English and to submit it exclusively to co-housing communities residing in English-speaking countries. The exception is the Spanish case of Los Portales, which is a co-housing community characterized by a very strong presence of international members who are used to speaking English. Moreover, this decision reduced the variety of sampling by concentrating the analysis on some countries, but, beyond the linguistic issues, this 
decision made it possible to compare cases in culturally similar countries and in which the restrictive measures adopted for the pandemic have tended to be similar too.

To engage the co-housing members, the authors contacted a community member for each co-housing community, inviting them to share the questionnaire with other community members. Those who took part in the research by answering the questionnaire did so on a completely voluntary basis: the authors informed them from the beginning that no incentives of any kind would be provided to those who took part in the research. The only requirements for answering the questionnaire were being of majority age and having lived in a co-housing community before and during the COVID-19 pandemic period.

\subsection{Survey}

The authors sent the following questionnaire, resulting from the design described above, to the selected communities and members thereof. The questionnaire was created on the Google Forms online platform (www.docs.google.com/forms) (accessed on 12 April 2020) and consisted of 40 questions, some of which had open answers and others closed answers. Of all these questions, only 17 were considered for the purpose of this research, which are proposed below.

Baseline characteristics

1. Name of your co-housing Community Open question

2. Country Selection from: Canada, USA, UK, Spain, Australia, and New Zealand

3. State/Region where your co-housing community is located Open question

4. Number of individuals in your community Selection from: $21-30 ; 31-40 ; 41-50$; more than 50

5. Which picture best represents the context of your community? Selection from pictures: Rural; Sub-urban; Urban; Historic Center; Outskirt; Forest

6. Your age Selection from: $18-30 ; 31-40 ; 41-50 ; 51-60 ; 61-70$; older than 71

7. Your sex Selection from: Female; Male; Prefer not to say; Non-Binary; Gender nonconforming Social interaction

8. How much has your way of socializing changed? Linear scale: $0=$ it worsened; $5=$ it did not change at all; $10=$ it improved

9. In what ways have the opportunities to meet other community members changed? Linear scale: $0=$ really reduced the opportunities to meet; $5=$ did not change at all; $10=$ really increased the opportunities to meet

10. How have open-air activities within the community changed? Linear scale: $0=$ really reduced the open-air activities; $5=$ did not change at all; $10=$ really increased the open-air activities

11. Did you suffer because of the (eventual) lack of social relations within the community? Linear scale: $0=$ not suffered at all; $10=$ I really suffered

12. Did you suffer because of the (eventual) lack of social relations outside the community? Linear scale: $0=$ not suffered at all; $10=$ I really suffered

13. In facing the emergency, do you think you have been luckier or not, compared with people living in traditional housing? Linear scale: $0=$ less lucky; $5=$ there is no difference; 10 = more lucky Spatial considerations

14. Do you think the way in which the community is using the COMMON spaces has changed? Linear scale: $0=$ no; $10=$ definitely yes

15. Are you still using the shared space? Linear scale: $0=$ no, we reduced the use of shared spaces a lot; $5=$ there is no difference from before; $10=$ yes, and even more than before

16. Are you still using the open-air shared space? Linear scale: $0=$ no, we reduced the use of open-air shared spaces a lot; $5=$ there is no difference from before; $10=$ yes, and even more than before

17. Do you think living in co-housing has made it easier to face the contingency? Linear scale: $0=$ no, living in co-housing made things harder; $5=$ there is no difference; $10=$ yes, living in co-housing made things easier 
Questionnaire surveys were conducted between May and June of 2020. A month after the first questionnaires were sent, 147 replies were received.

\subsection{Statistical Analysis}

The survey collected data from 147 subjects (all aged over 18 years old) from 52 co-housing communities. Since 60 co-housing communities were selected to answer the survey, the overall response rate for the communities was $87 \%$. The authors cannot know the overall response rate for the residents for two reasons: (1) to facilitate the answers, question four gives the community dimension only by range; and (2) having directly contacted only the community member in charge of external relations, it was not possible to determine how many residents actually received the questionnaire. However, the high response rate from the communities ( $87 \%$ collaboration) shows that results are representative and that the survey performed as intended.

Firstly, with the aim of highlighting general behavior and to show the overall tendencies, an analysis of each question was performed using averages. Secondly, with the aim of highlighting the behavior of groups, correlations between 'baseline characteristics' questions, related to context, gender and age, were analyzed together with the 'social interactions' and 'spatial considerations' questions. All analyses were performed with commercially available software (Excel and Jmp v 14).

\section{Results and Discussion}

To understand how the outbreak affected co-housing communities, the authors took into account all the questions answered in the survey which revealed important information regarding the two topics of interest to the research: socializing and spaces, which in the end can be summarized in the perception of how desirable it is to live in a co-housing community during a pandemic (Appendix B). For this reason, the first topic analyzed by the survey is how the members of a co-housing community perceive the variation of their social interaction within and outside the community. The second topic analyzed by the survey regards the spatial characteristics and elements that are considered to contribute (positively or negatively) to the way people can interact.

Gender differences was the only variable used to analyze the answers (Figure 1), since most of the respondents were over 60 years old and, consequently, age differences couldn't be considered relevant enough. The reasons why older people represented the majority of the people who answered the survey are: (1) this generally traces the demographic distribution of age ranges in the co-housing community studied; and (2) the older people interviewed claimed to be retired and to have time to answer the survey.

Moreover, authors want to underline how the higher percentage of women answering the survey could be considered common and predictable. In fact, as extensively analyzed by several researchers into response rates, women tend to respond to physical and online surveys at greater rates than men $[86,87]$.

\subsection{Social Interaction: How Has Socialization Changed?}

As previously mentioned, socializing is at the core of co-housing communities, since social activities, shared duties, and organized events are always present and represent opportunities to enhance socialization and a sense of belonging. At the same time, all the cohousing communities are open to their context and have important social interactions with the external community. During the outbreak, both internal and external social activities had to stop, and the residents had to suffer the consequent social distancing. Therefore, to evaluate its impact on people and their social wellness, the survey required us to analyze both types of social activity. 


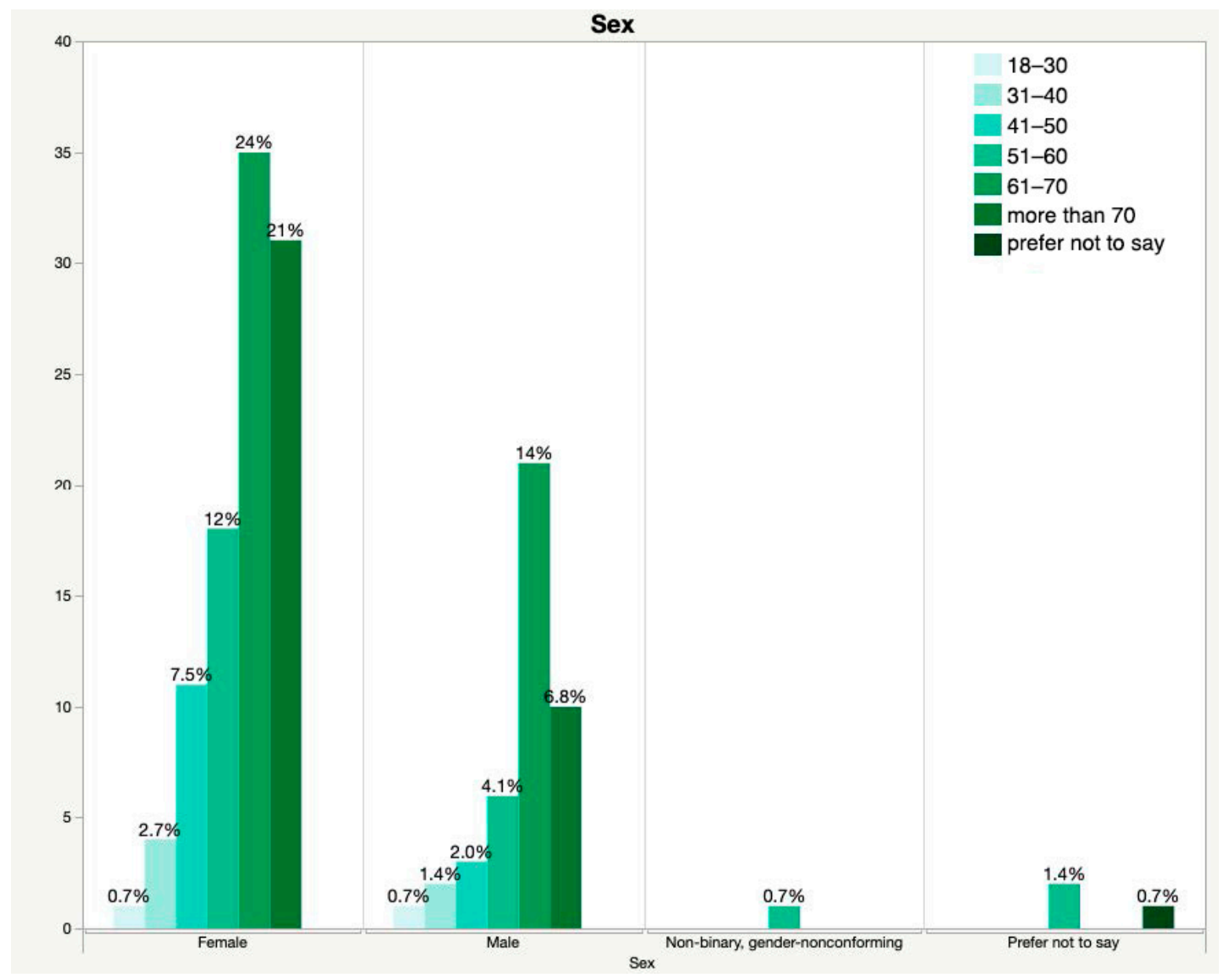

Figure 1. Demographic structure of the respondents, according to their gender and age.

\subsubsection{Ways of Socialization}

Regarding the perception of a change in the level of socialization with the other members of the co-housing community, almost $75 \%$ of the people perceived that it was worsening, and female respondents appear to be much more affected than male (Figure 2). When we compare these results with the answers to the question about how they think the way of socializing has changed (Figure 3) during the first months of the lockdown in each of their locations, it is interesting that the answers change a little: from being more pessimistic when thinking about the way socializing has changed to a more moderate evaluation of the changes.

When looking at the responses to the question regarding the way meeting other community members has changed, most of the respondents (78\%) said that it reduced the opportunities, females once more being the most affected (Figure 4).

\subsubsection{Within and Outside a Co-Housing Community}

At a more granular scale, it was also asked in the survey if the inhabitants suffered from the eventual lack of social relation within and outside the co-housing community (Figures 5 and 6). It was called to our attention that for the social relations within the community, the answers are almost even: while $46 \%$ responded that they suffered because of this, $44 \%$ of the respondents did not suffer at all and $10 \%$ think that those relationships remained the same. Figure 5 shows in detail the contrast between male and female respondents regarding how much they perceived the lack of social relations within the community. Males tended to feel less affected by this condition (57\%) than females, with only $36 \%$ (from "almost remaining the same" to "not suffered at all"). 


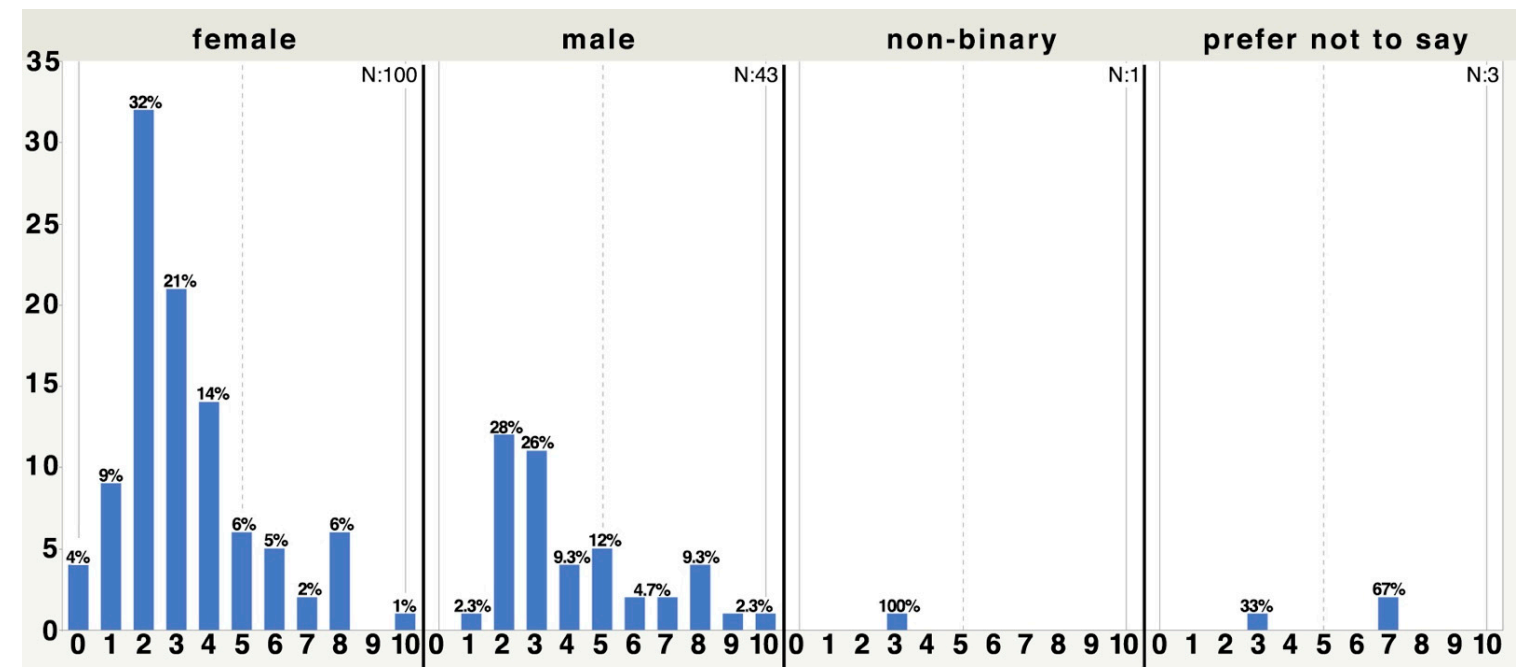

Figure 2. Question: How much has the way of socializing changed? (Range of answers go from 0 (got worse) to 5 (did not change at all) to 10 (improved)).

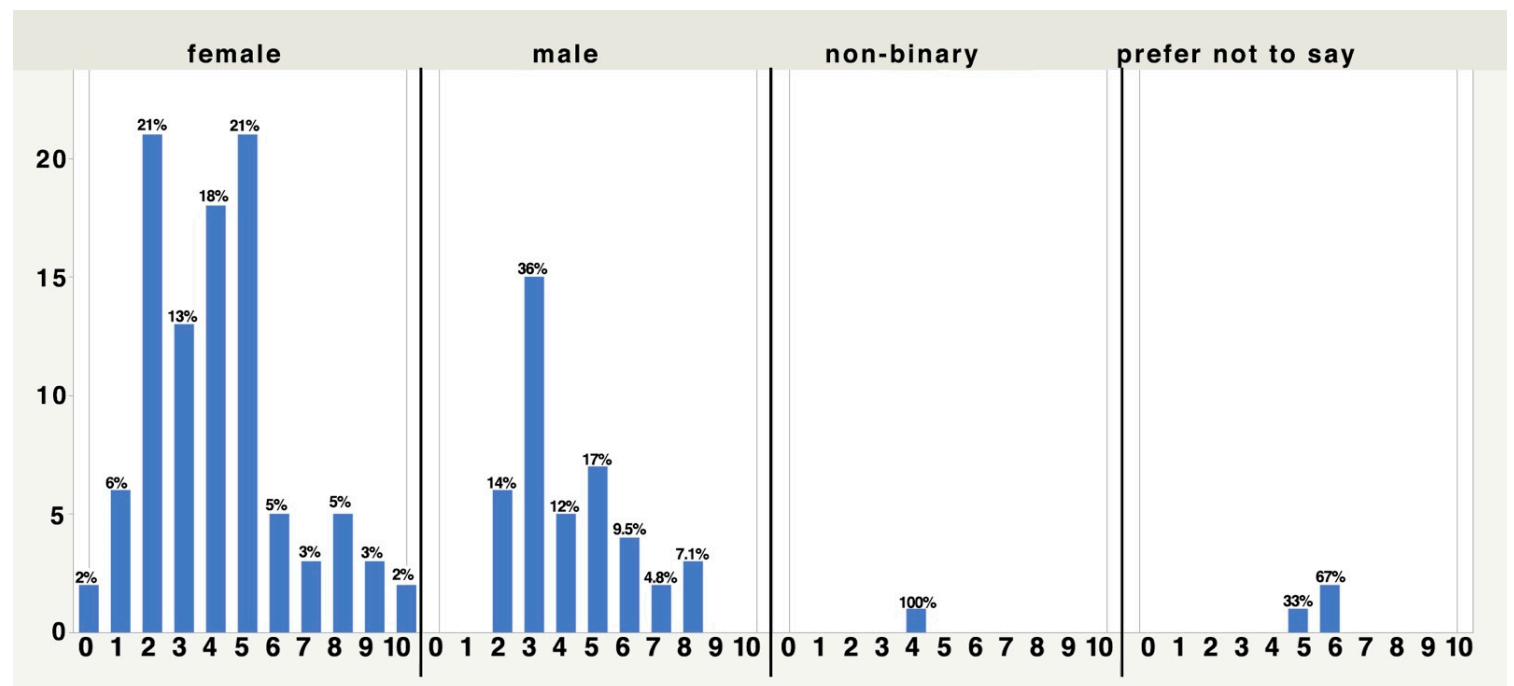

Figure 3. Question: How would you evaluate changes in the way of socializing? (Range of answers go from 0 (very bad) to 10 (very good)).

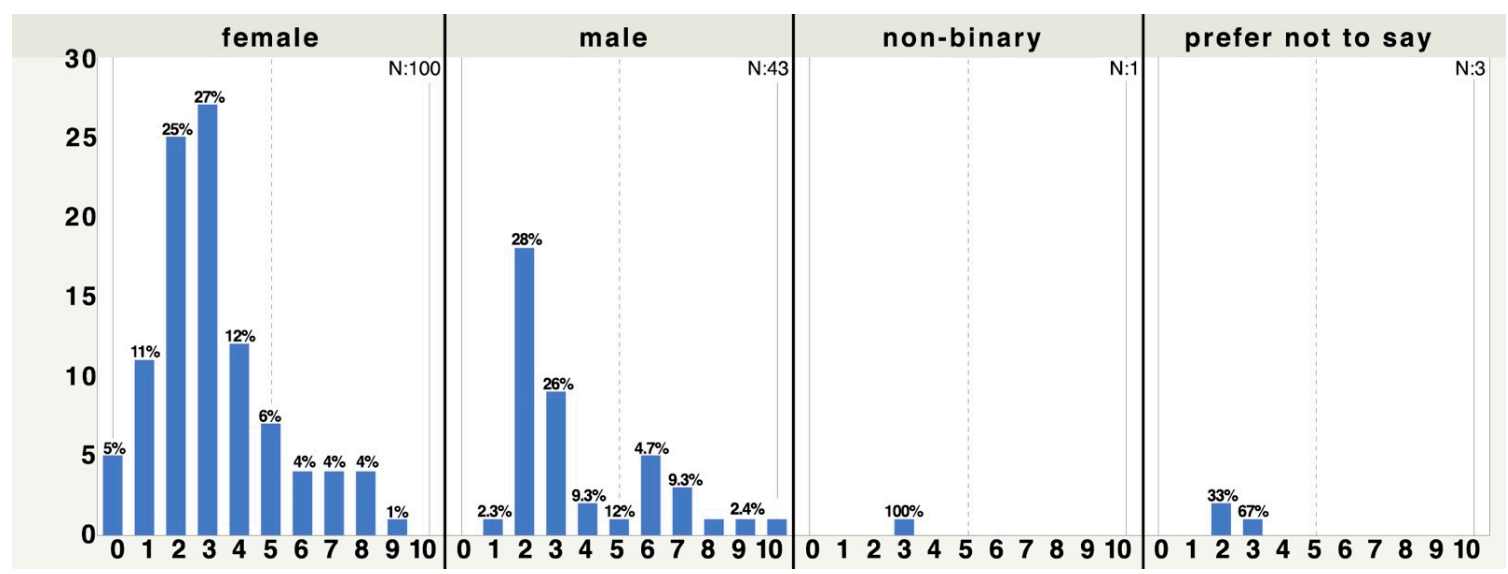

Figure 4. Question: How much has the way to meet other community members changed? (Range of answers go from 0 (really reduced the opportunities to meet) to 5 (did not change at all) to 10 (really increased the opportunities to meet)). 


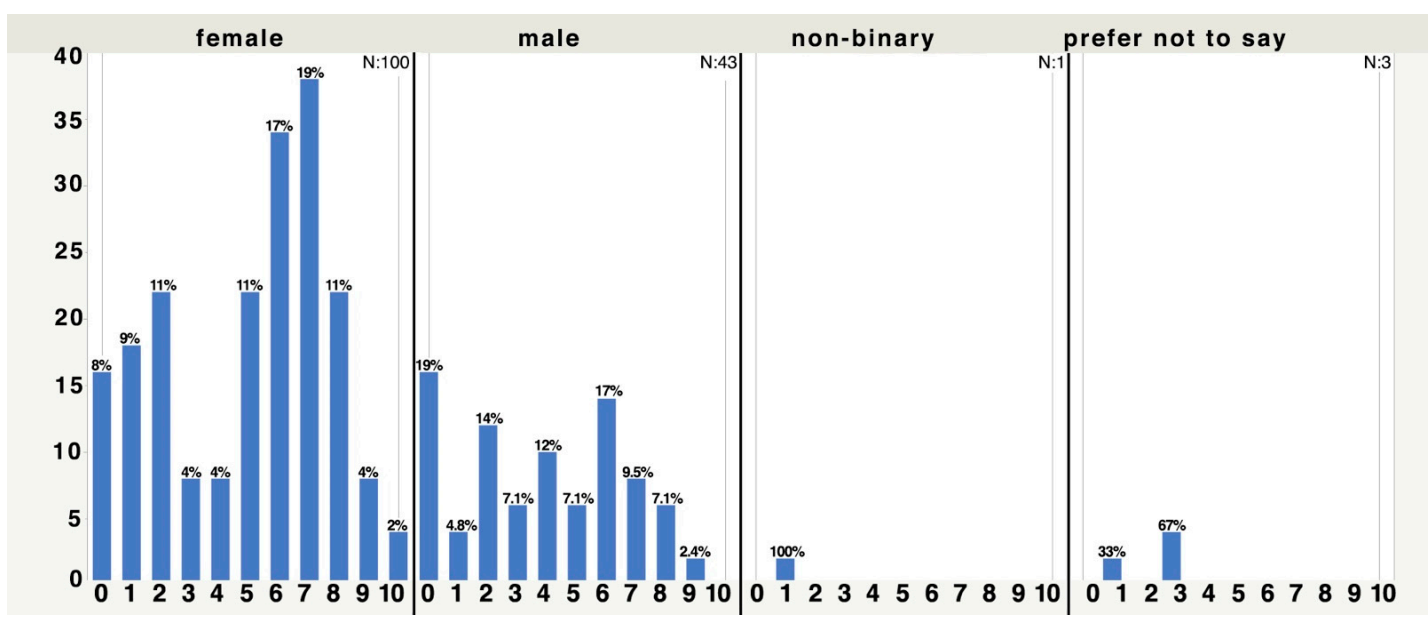

Figure 5. Question: Did you suffer for the (eventual) lack of social relation within the community? (Range of answers go from 0 (not suffered at all) to 5 (remained the same) to 10 (really suffered)).

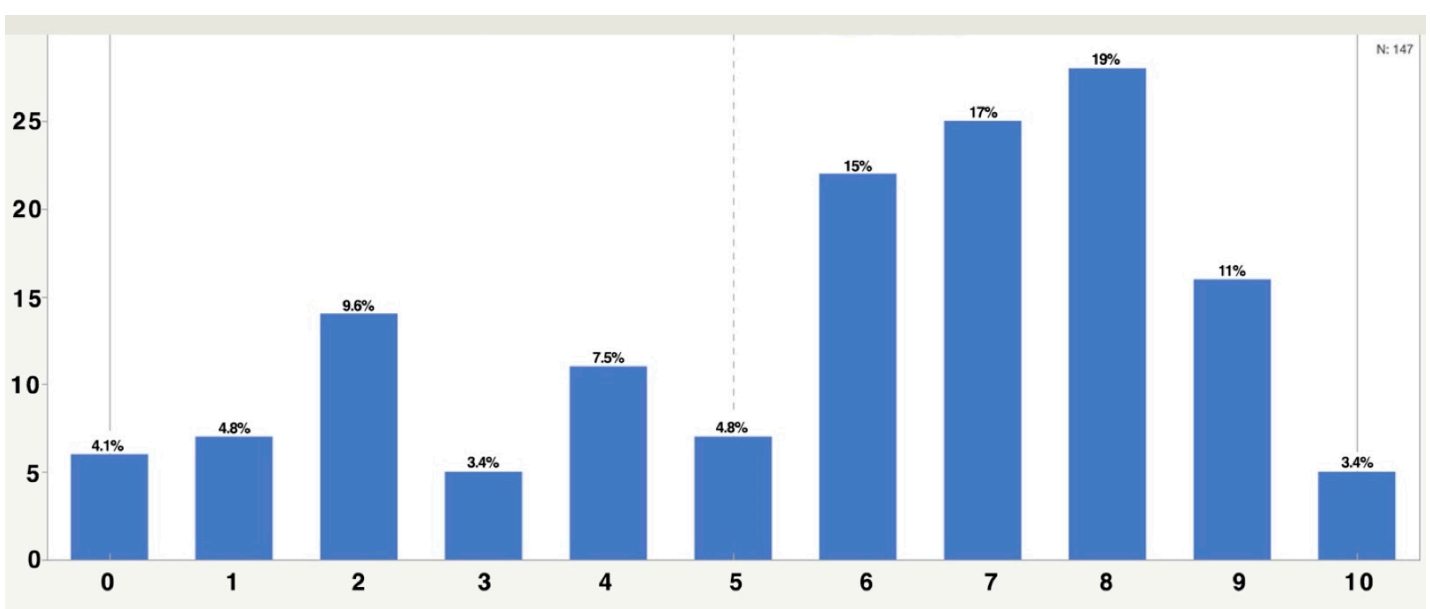

(a)

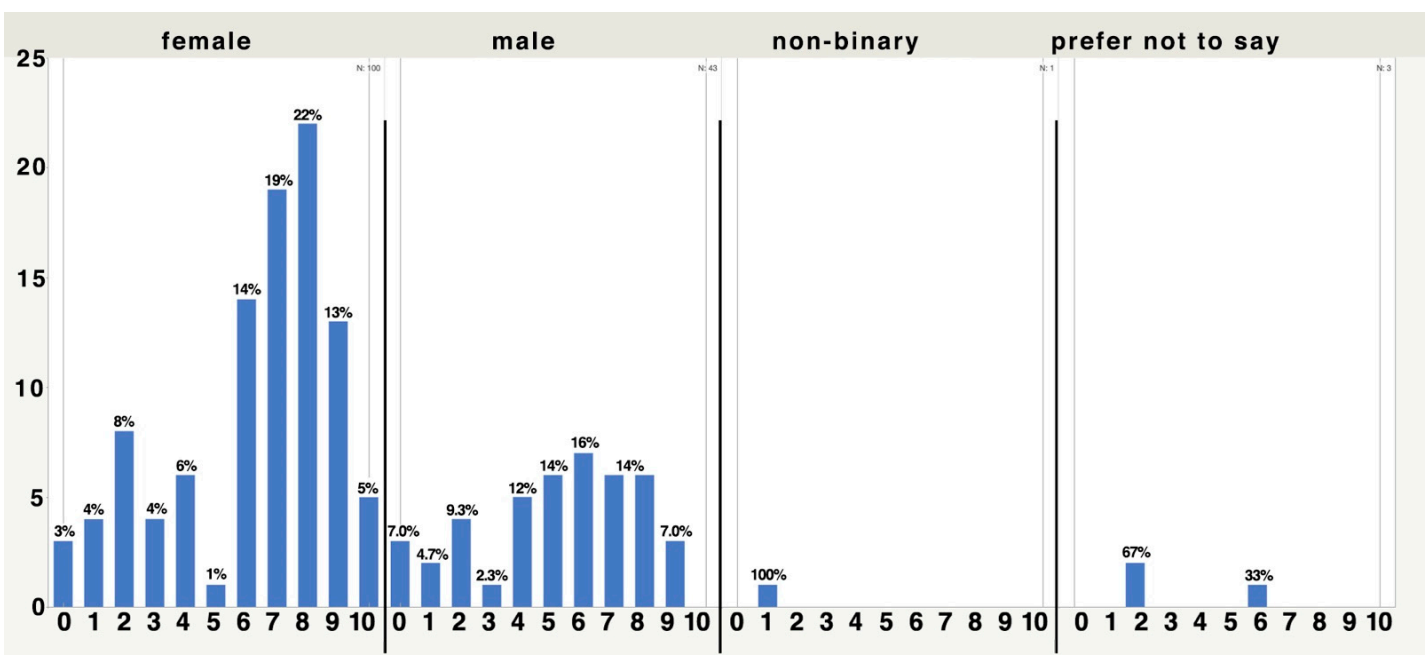

(b)

Figure 6. (a) Overall results to the Question: Did you suffer from (eventual) lack of social relations outside the community? (Range of answers go from 0 (not suffered at all) to 5 (remained the same) to 10 (really suffered)). (b) Results to the Question by gender: Did you suffer from (eventual) lack of social relations with people outside the community? (Range of answers go from 0 (not suffered at all) to 5 (remained the same) to 10 (really suffered)). 
Regarding the possibility of having social interaction with people outside the community, the answers are as seen in the overall results shown in Figure 6a: only $29 \%$ did not suffer from this situation, $5 \%$ thought that it was the same as when there was no lock-down, and $65 \%$ perceived a negative change, women being the most affected. Again, when looking at the results by gender, females were the most affected with a ratio of almost one to three: $25 \%$ of them did not suffer and $73 \%$ suffered from the lack of social relations outside the community (Figure $6 \mathrm{~b}$ ). For this question, half of the male respondents were also affected by a lack of social interaction and a little bit more than a third of them (35\%) did not feel affected. It came to our attention that $14 \%$ of males reported feeling the same.

Therefore, it can be concluded that: even if socialization (shared events, activities, work, etc.) stopped for the pandemic, the presence of a community and of a sense of belonging helped in the perception of community support and led to less suffering from a lack of social relations.

\subsection{The Use of Common/Shared Space}

The survey also focused on people's perception about the use of the common or shared space within a co-housing community. For this section, five questions were asked:

- $\quad$ The first question was related to the respondent's perception regarding the differences in the way of using the common spaces;

- The second, third, and fourth questions gave us an idea of which shared spaces (mainly between indoor and outdoor) were the most used during the outbreak;

- The last question explored how much the members of the community adapted any space, considering their new situation.

When asking them about their perception of the use of the common spaces by the community, there was an overwhelming majority $(72 \%)$ who thought that it had definitely changed. If we look at the results by gender, we can see that even when everyone thought that it had changed, male respondents were a little more moderate in their answers: only $58 \%$ said it had definitely changed compared with $79 \%$ of females, while $12 \%$ of males answered with a 7 and 8 , compared with $3 \%$ and $4 \%$, respectively, of females (Figure 7 ).

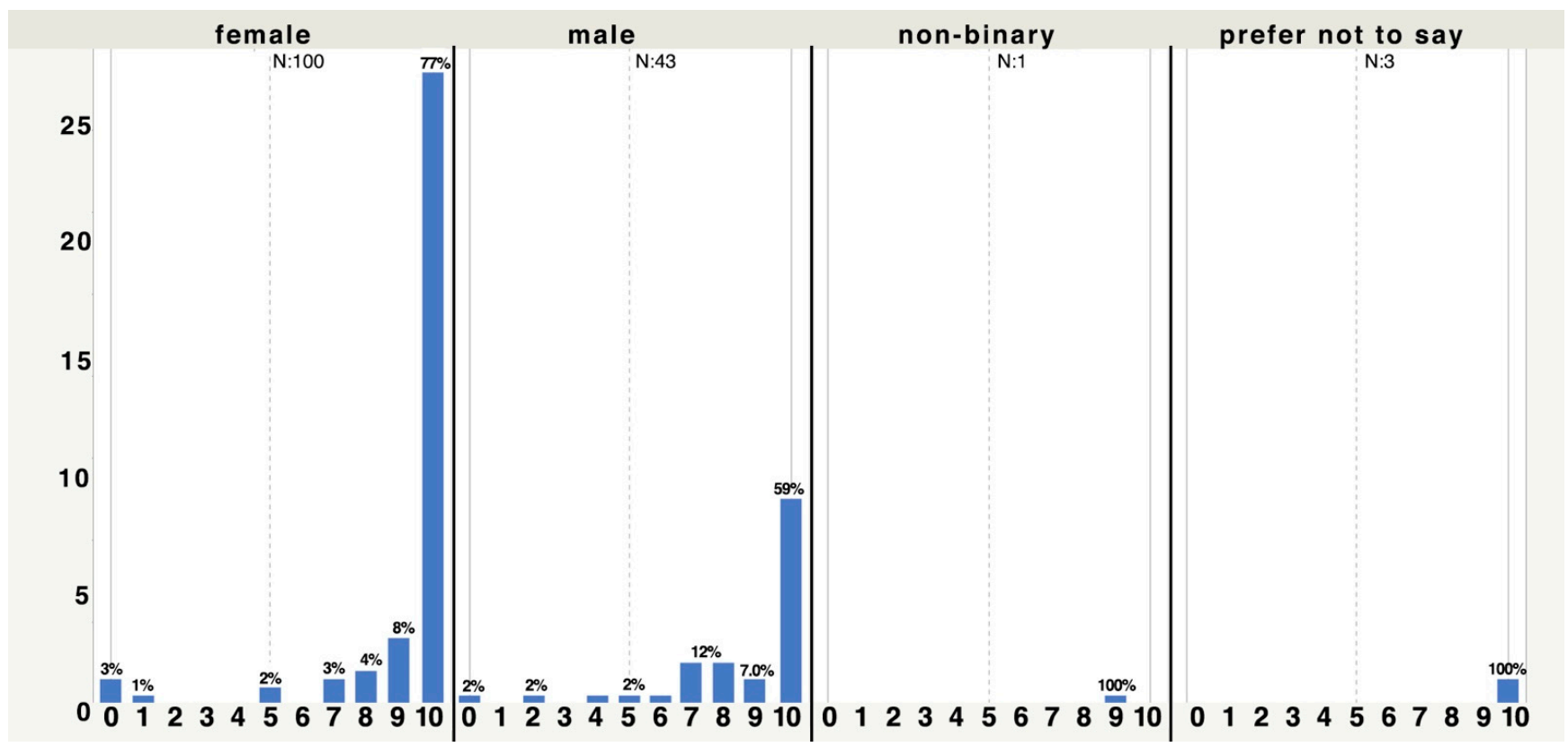

Figure 7. Question: Do you think the way in which the community is using the COMMON spaces has changed? (Range of answers go from 0 (no) to 10 (definitely yes)). 
It is remarkable how the residents changed a very significant part of their way of living by reducing the use of shared spaces significantly: $71 \%$ of the respondents were in the range of $0-2$ (Figure 8). In all probability, the $18 \%$ of respondents (those within the range of 5 to 10) who answered that they were using the shared spaces even more than before, were taking advantage of the possibility of having the space for themselves.

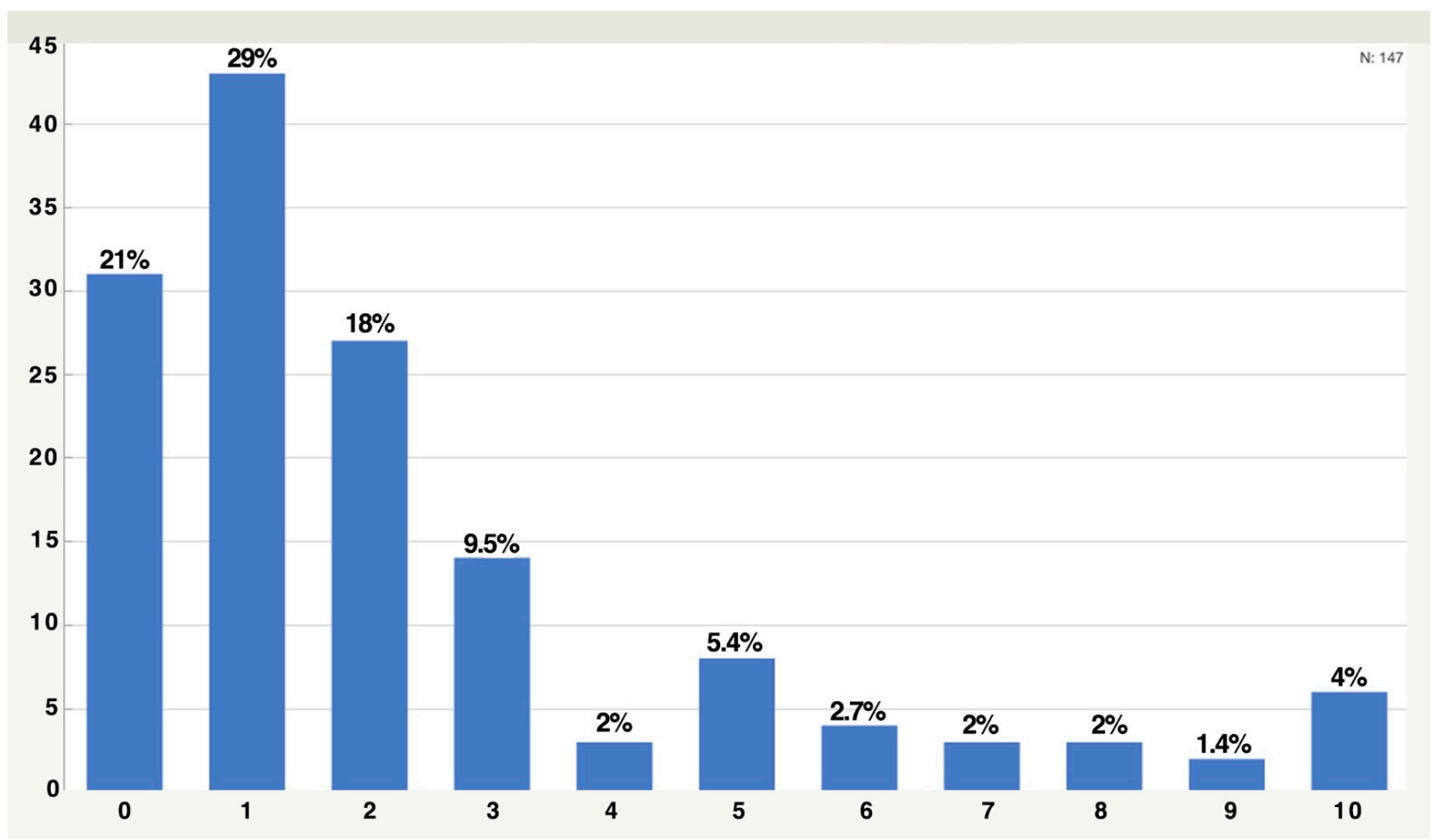

Figure 8. Question: Are you still using the shared space? (Range of answers go from 0 (no, we reduced the use of shared spaces a lot) to 5 (there is no difference from before) to 10 (yes, and even more than before)).

It is interesting to observe how different the answers to two very similar questions can be, regarding the use of open-air spaces and the activities related to these (Figure 9a,b). While almost $40 \%$ of the respondents (we are observing those whose answer was 9 and 10) were using the open-air spaces even more than before the pandemic (Figure 9a), the perception about the intensity of use of these spaces seems more evenly spread among three groups: reduced $(21 \%)$, not changed $(31 \%)$, and those who thought that it really increased (48\%) (Figure 9b).

In terms of the capacity of the compound to support all the activities of its inhabitants, two related questions were asked. The first question was regarding the need to adapt any communal space and the second was more specific about which space was adapted. As seen in Figure 10a, more than half of the respondents agreed that there was a need to change the common spaces. Therefore, we enquired if there was a special room that needed to be changed (Figure 10b). Among the 325 answers from the respondents, three spaces stand out from the list: the whole common house, then the guest room, and in third place, the kitchen. In order to have a better understanding of these changes, we asked for adjectives to describe the changes in the use of common spaces and the results are interesting: the most recurrent description that came to their mind was that this was going to be temporary, but these changes can have three different directions: one is that they are negative (about $36 \%$ of the respondents said so), the second is quite the opposite, because $33 \%$ of inhabitants see these changes as useful and, finally, the unplanned was marked by $30 \%$ of the respondents. 
45

40

35

30

25

20

15

10

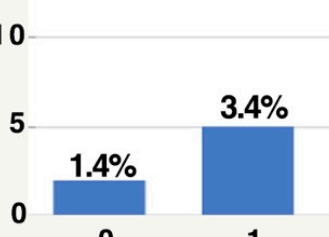

12
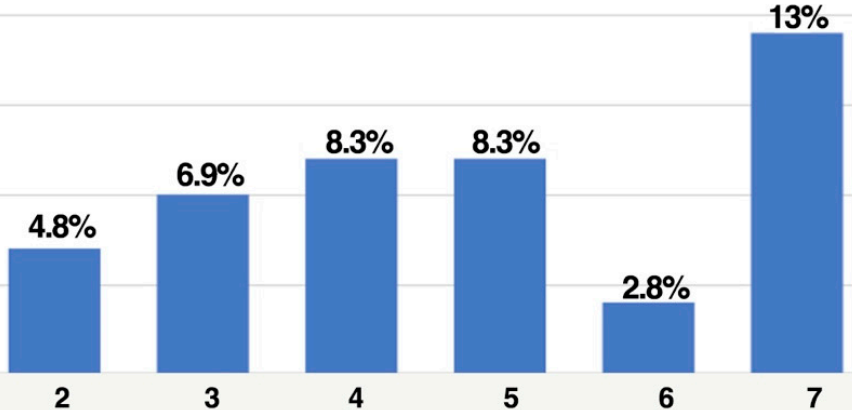

$12 \%$

(a)

\section{5}

$14 \%$

20

15

$10 \%$

5

10

$6.8 \%$

0
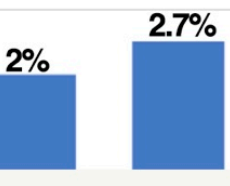

1

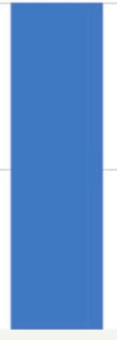

2

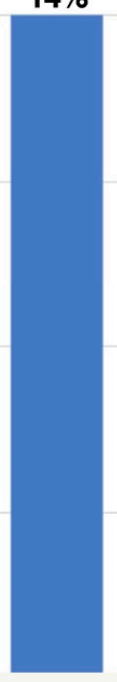

4

$16 \%$

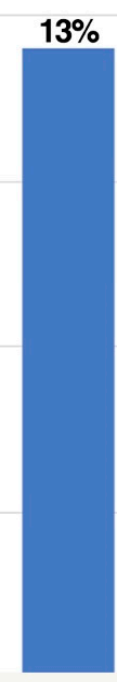

5

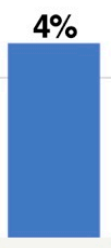

6

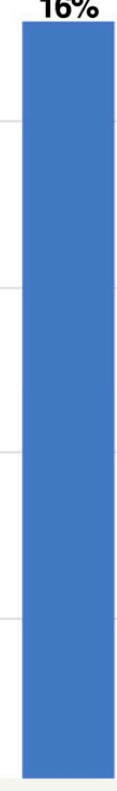

7 (b)
$14 \%$

$7.5 \%$

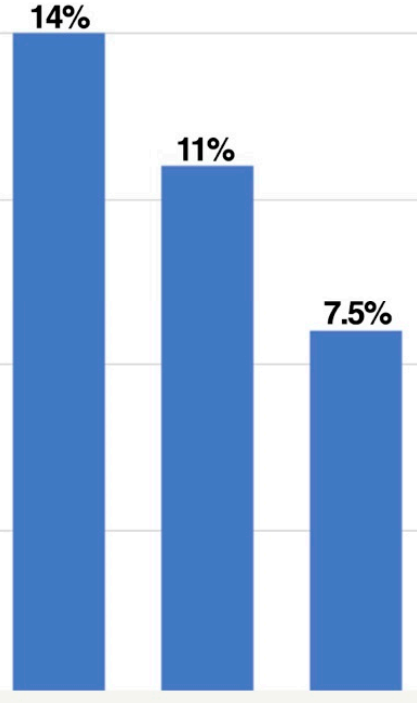

9

10

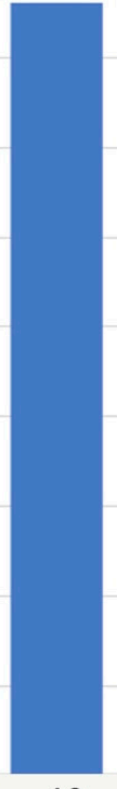

10

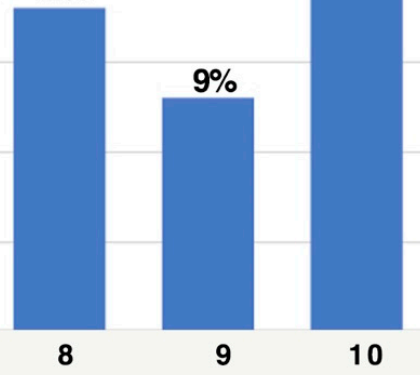

Figure 9. (a) Question: Are you still using the open-air shared space? (Do you think living in co-housing has made it easier to face the contingency?) (Range of answers go from 0 (no) to 10 (even more)). (b) Question: How much have the open-air activities within the community changed? (Range of answers go from 0 (really reduced the open-air activities) to 5 (did not change at all) to 10 (really increased the open-air activities)). 


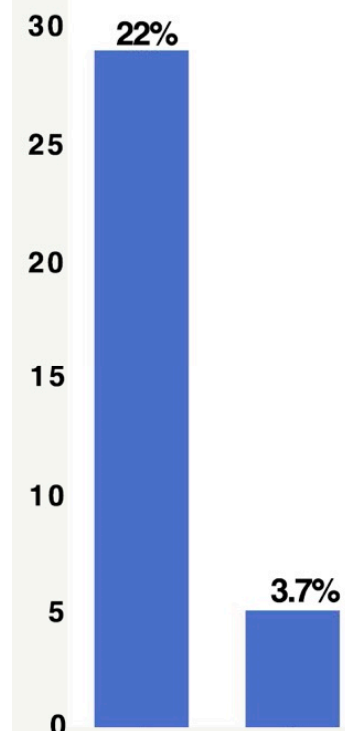

0

1

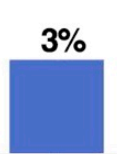

2

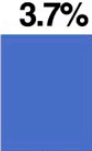

3
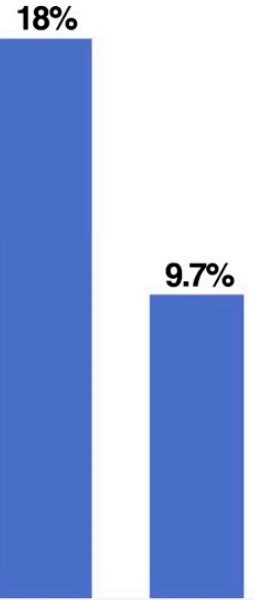

8

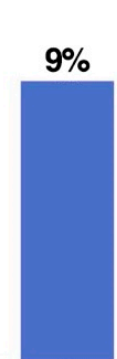

9
$10 \%$

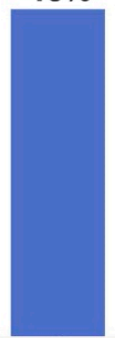

10

(a)

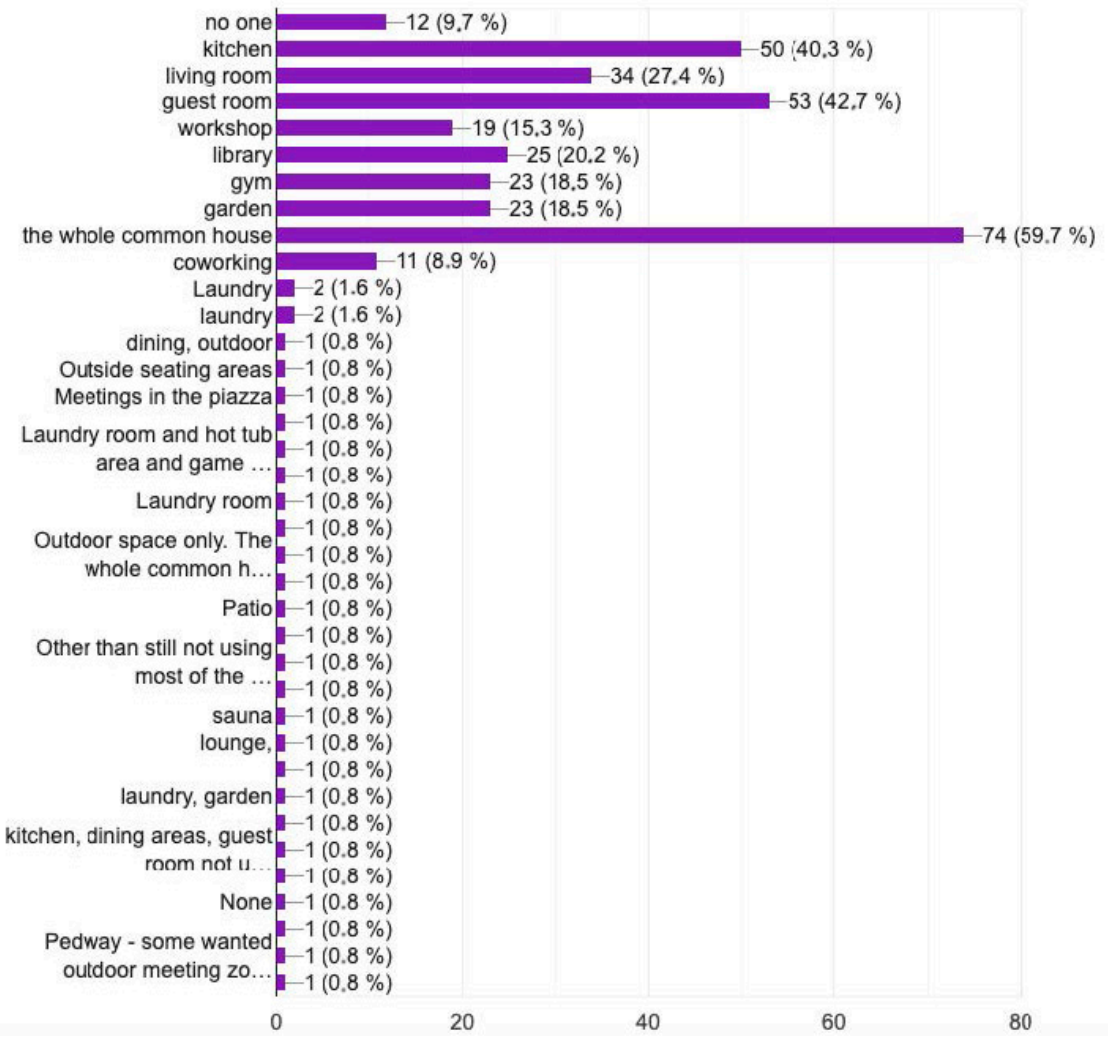

(b)

Figure 10. (a) Question: Did you need to adapt any space of the community? (Range of answers go from 0 (no) to 10 (radical changes)). (b) Question: Which common/shared spaces have been adapted? 


\subsection{Sense of Gratitude for Living in Co-Housing}

Finally, we asked the respondents to describe how fortunate they are living in a cohousing precinct. Four out of ten respondents think that living in a co-housing community has made things easier. On this occasion, we decided to present the results divided according to the gender category. The light blue bars in Figure 11 show that $83 \%$ of females are pleased with the decision of living in a co-housing community, as well as $62 \%$ of male respondents. To be completely sure about how satisfied they feel compared with their idea of living in a traditional housing compound, with regard to the pandemic, we asked if they feel luckier or not, compared with people living in traditional housing (dark blue bars of Figure 11): 50\% of the overall respondents feel luckier (an increase of 10\% compared with the previous question). Again, when looking at the answer by gender, both genders showed an increased figure of five percentage points: females answered positively with an overwhelming $88 \%$, while $66 \%$ of males think they are luckier. Therefore, according to the perception of those who answered the survey, living in co-housing is much better than in traditional housing. Furthermore, analyzing the results of this question, it must be noted that respondents are only co-housing residents and, tendentially, they should have, as background, a positive consideration about their housing tenure. Even if this implies that positive answers could be predictable, two aspects validate these answers as a particularly positive evaluation of co-housing potentialities: (1) the fact that almost all the residents have previous experiences of non-co-housing communities; and (2) the appreciation level is very high.

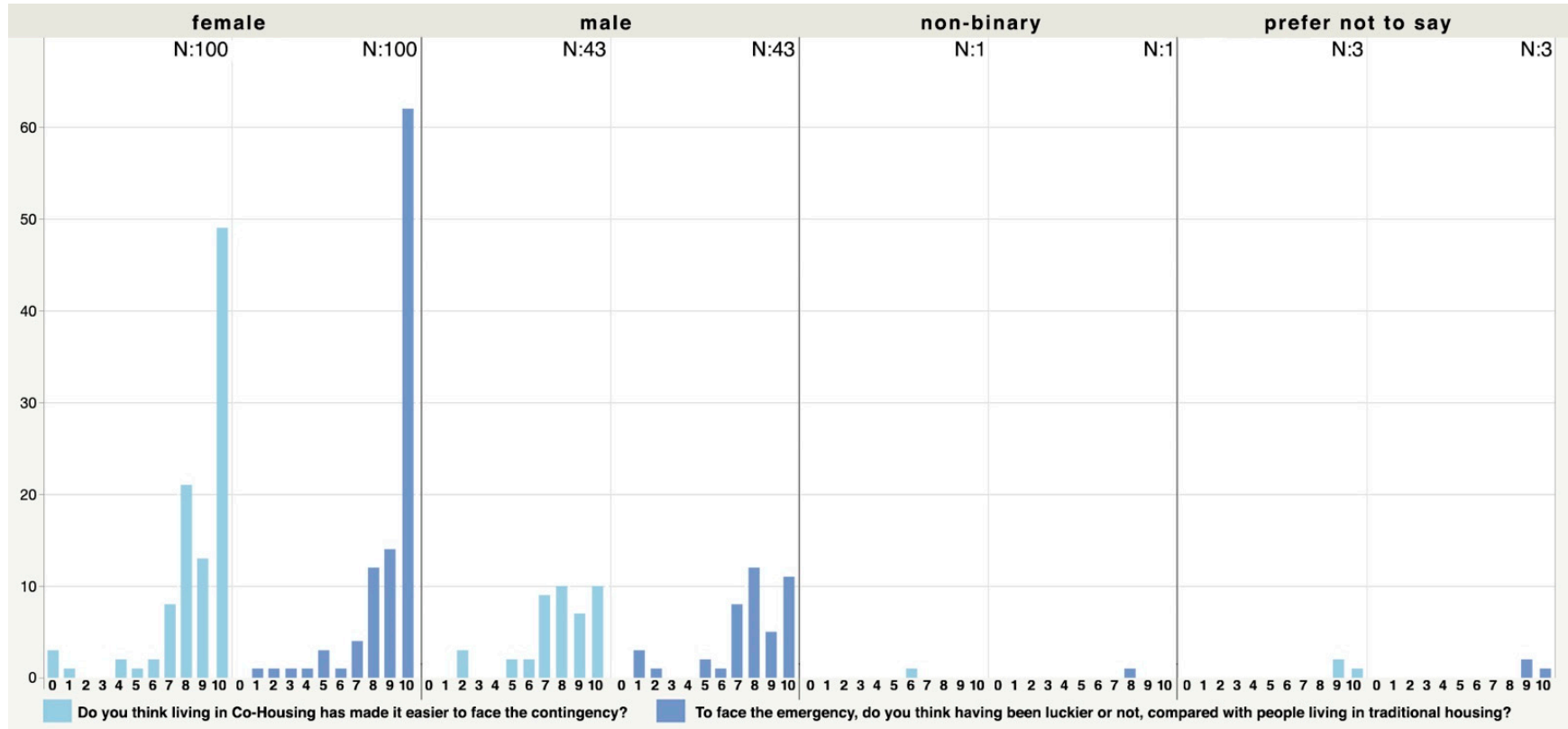

Figure 11. Questions: Do you think living in co-housing has made it easier to face the contingency? In facing the emergency, do you think you have been luckier or not, compared with people living in traditional housing? (For the first question, the range of answers go from 0 (no, living in co-housing made things harder) to 5 (there is no difference) to 10 (yes, living in co-housing made things easier). For the second question, the range of answers go from 0 (less lucky) to 5 (there is no difference) to 10 (more lucky)).

\section{Conclusions}

This research highlights two aspects which are among the main challenges for contemporary cities: (1) having a sense of belonging at the level of local communities; and (2) being able to consider open areas as a common, shared, and safe asset of the local community.

Even if the way of life has radically changed and the opportunities for socializing within a co-housing community, as well as the use of shared spaces, have radically de- 
creased, it is very interesting to observe how the negative perception of a lack in social relations is stronger when associated with external members (relatives, colleagues, friends, etc.) and minimal when associated with other community members. Similarly, the vast majority of respondents say they are definitely happy to be part of a co-housing community and believe that being part of a community helped to make the emergency less difficult. This observation shows the importance of belonging to a local community as a way to reduce dissatisfaction generated by limited social relations; this is of extreme importance when such a consideration is extended to contemporary cities, where strong individualism and the loss of mutual supportive social relationships are a recognized cause of social problems. Urban-architectural design must be able to enact local solutions that foment the generation of a sense of belonging and community.

On the other hand, a very relevant aspect that emerged from this research is the role that open-air shared spaces have had during the confinement: not only have they continued to be used, but, in several cases, they have had more use than before. This aspect highlights a couple of important design considerations: (1) on the side of co-housing communities, shared open spaces are not exploited as much as they could be as an element of community creation and, in the design of new communities, these spaces should assume an even more important role in the management of the community's social activities; and (2) from the design side, not referring to co-housing communities, it is very relevant to highlight how open-air common spaces must undoubtedly have a totally new strategic importance in post-pandemic cities. This is produced by their properties of building community and because they provide key common spaces in addition to private space.

Undoubtedly, this study suffers from some limitations. The most relevant one is associated with the decision to limit the case studies to only English-speaking communities (considering English-speaking countries and the case of the "international" Spain community), to reduce the possibility of inaccuracies in comparing questionnaires in different languages. Therefore, the respondents' perception of the pandemic (and consequently their answers) could be influenced by the fact that they live in countries (Canada, the United States, Australia, Spain, and the UK) which imposed similar restrictions and that are totally different from the limitations imposed in countries such as India, China, or Brazil. This implies that surveys from co-housing communities in countries which applied substantially different restrictions could reveal different results. Nevertheless, at the same time, even if restrictions and limitations can be considered similar if compared with countries where the response to the pandemic has been very different (as assumed by the researchers), readers should be warned that local scale differences in infections and restrictions surely affected both the way in which each community reacted to the pandemic and, consequently, the survey outcomes.

Another aspect of this research that must be underlined is that the work doesn't promote a comparison with perceptions between co-housing residents and non-co-housing residents. For this reason, residents living in traditional housing were not involved in the research. While this issue could be considered as a limitation, particularly regarding the effectiveness of co-housing to face the pandemic (question 17), it should also be considered as a key issue for further research that can emerge from these results to more deeply analyze the benefits of co-housing communities compared with non-co-housing options.

Furthermore, it will be interesting to compare these results with a further study that will be conducted again in a few months, to see how the perception of community members has evolved and, in particular, what measures (physical or relational) have been adopted to recover any form of shared and common life. For the same reason, a further study will have to be carried out once the pandemic is over and a situation in which social distancing is no longer necessary has returned. This future research will aim to highlight some organizational changes or spatial arrangements that have been adopted by communities following the pandemic. 
Author Contributions: Conceptualization, E.G., L.M.L., R.G.-M., A.K., C.C. and M.A.M.; methodology, E.G., L.M.L., R.G.-M., A.K., C.C. and M.A.M.; software, E.G. and R.G.-M.; validation, E.G., L.M.L., R.G.-M., A.K., C.C. and M.A.M.; formal analysis, E.G., L.M.L., R.G.-M., A.K., C.C. and M.A.M.; resources, L.M.L., A.K., C.C. and M.A.M.; data curation, E.G. and R.G.-M.; writing-original draft preparation, E.G., L.M.L., R.G.-M., A.K., C.C. and M.A.M.; writing-review and editing, E.G., L.M.L., R.G.-M., A.K., C.C. and M.A.M.; visualization, R.G.-M.; supervision, E.G. All authors have read and agreed to the published version of the manuscript.

Funding: This publication was funded by "Fondo para el financiamiento para la publicación de Artículos Científicos" (Tecnologico de Monterrey, 2021) and the English proofreading by the 2019 "CITRIS + Tecnologico de Monterrey Seed Funding".

Institutional Review Board Statement: Not applicable.

Informed Consent Statement: Not applicable.

Data Availability Statement: The data presented in this study are available on request from the corresponding author.

Acknowledgments: The research project was performed thanks to the support of all the community members who participated in the survey: this work couldn't have been performed without their important participation. In particular, a special gratitude goes to the Co-Housing Research Network and to its Steering Committee. The authors would like to thank all those who have supported the activities of this research or have provided valuable comments on methodology and the earlier versions of this paper, particularly Roberto Iñiguez Flores, Alfredo Henry Hidalgo Rasmussen, and Neil Hernández Gress.

Conflicts of Interest: The authors declare no conflict of interest.

\section{Appendix A}

This first appendix aims to collect and resume the most relevant references used to define the current state of the research field. The authors decided to add this appendix, in the form of a table, since the research topic is extremely new and a recapitulatory chart could help to better cement the ideas.

Table A1. Summary of literature review, sources and main topics covered ( 1 = COVID-19 outbreak; $2=$ Housing; 3 = Isolation; 4 = Co-housing; 5 = Quality of life; $6=$ Mental Health; 7 = Open-air spaces; $8=$ Urb $/$ arch. elements that contributed during isolation).

\begin{tabular}{|c|c|c|c|c|c|c|c|c|c|}
\hline \multirow{2}{*}{ Reference } & \multirow{2}{*}{ Keywords } & \multicolumn{8}{|c|}{ Main Topics } \\
\hline & & 1 & 2 & 3 & 4 & 5 & 6 & 7 & 8 \\
\hline $\begin{array}{l}\text { Amerio; Brambilla; Morganti; } \\
\text { et al., } 2020\end{array}$ & $\begin{array}{l}\text { COVID-19; Lockdown; Housing Built } \\
\text { Environment; Mental Health; } \\
\text { Evidence-Based Design }\end{array}$ & $\mathrm{x}$ & $\mathrm{x}$ & $\mathrm{x}$ & & $\mathrm{x}$ & $\mathrm{x}$ & & \\
\hline $\begin{array}{l}\text { Babos; Szabó; Orbán \& Benko, } \\
2020\end{array}$ & $\begin{array}{l}\text { Co-housing; Cohousing; Urban Housing; } \\
\text { Collective Housing; Housing Classification; } \\
\text { Housing Categorization; Participation; Field } \\
\text { of Sharing; Social Sharing }\end{array}$ & & $\mathrm{x}$ & & $\mathrm{x}$ & & & & \\
\hline Bettaieb; Alsabban, 2020 & $\begin{array}{l}\text { Housing; Flexibility; Adaptability; } \\
\text { COVID-19; Lifestyle }\end{array}$ & $\mathrm{x}$ & $\mathrm{x}$ & $\mathrm{x}$ & & $x$ & & & $\mathrm{x}$ \\
\hline Bigonnesse, 2012 & $\begin{array}{l}\text { Aging In Place; Co-housing Community; } \\
\text { Naturally Occurring Retirement Community; } \\
\text { Neighborhood Environment; Constructivist } \\
\text { Grounded Theory; Photovoice Interviews }\end{array}$ & & $\mathrm{x}$ & & $\mathrm{x}$ & $\mathrm{x}$ & & & \\
\hline Boonstra, 2016 & Behavior; Co-housing; Mapping & & $x$ & & $\mathrm{x}$ & & & & \\
\hline Chakraborty \& Maity, 2020 & $\begin{array}{l}\text { COVID-19; Pandemics; Global Health; } \\
\text { Economic; Prevention }\end{array}$ & $\mathrm{x}$ & & & & & & & \\
\hline
\end{tabular}


Table A1. Cont.

\begin{tabular}{|c|c|c|c|c|c|c|c|c|c|}
\hline \multirow{2}{*}{ Reference } & \multirow{2}{*}{ Keywords } & \multicolumn{8}{|c|}{ Main Topics } \\
\hline & & 1 & 2 & 3 & 4 & 5 & 6 & 7 & 8 \\
\hline $\begin{array}{l}\text { D'Alessandro, Gola; Appolloni, } \\
\text { Dettori; Fara; Rebecchi; Settimo; } \\
\text { Capolongo, } 2020\end{array}$ & $\begin{array}{l}\text { COVID-19 Living Spaces; COVID-19 } \\
\text { Housing; COVID-19 Built Environment; } \\
\text { Public Health Recommendations; Healthy } \\
\text { Living Spaces; Safe and Sustainable Housing; } \\
\text { Sustainable Architecture; Indoor Air Quality; } \\
\text { Water Consumption; Wastewater } \\
\text { Management; Urban Solid Waste } \\
\text { Management; Housing Automation }\end{array}$ & $x$ & $x$ & & & $\mathrm{x}$ & & & $x$ \\
\hline Delendi, 2017 & $\begin{array}{l}\text { Co-housing; Eco-Villages; Living Models; } \\
\text { Sustainability }\end{array}$ & & $x$ & & $\mathrm{x}$ & & & & \\
\hline Giorgi, 2020 & $\begin{array}{l}\text { Technocene; Co-housing; Sharing; } \\
\text { Case-Study }\end{array}$ & & $x$ & & $x$ & & & $x$ & \\
\hline Glass, 2020 & $\begin{array}{l}\text { Neighbors; Senior Co-housing; Living } \\
\text { Arrangements; Aging Better Together }\end{array}$ & & $x$ & & $x$ & $x$ & & & \\
\hline $\begin{array}{l}\text { Jacques-Aviñó, López-Jiménez; } \\
\text { Medina-Perucha; et al., } 2020\end{array}$ & $\begin{array}{l}\text { Gender; Social Impact; Mental Health; } \\
\text { COVID-19; Lockdown }\end{array}$ & $x$ & & $\mathrm{x}$ & & & $x$ & & \\
\hline Jarvis, 2011 & $\begin{array}{l}\text { Co-housing; Daily Life; Collective; Shared } \\
\text { Space; Ethnography }\end{array}$ & & $x$ & & $\mathrm{x}$ & $\mathrm{x}$ & & & \\
\hline Lang, Carriou \& Czischke, 2020 & $\begin{array}{l}\text { Collaborative Housing; Literature Review; } \\
\text { Conceptualization; Ontological } \\
\text { Categorization; Collective Self-organized } \\
\text { Housing }\end{array}$ & & $x$ & & $x$ & & & & \\
\hline Le \& Nguyen, 2020 & $\begin{array}{l}\text { COVID-19; Psychological Consequences; } \\
\text { Mental Health; Lockdowns; Stay-at-home } \\
\text { Orders }\end{array}$ & $x$ & & $x$ & & $\mathrm{x}$ & & & \\
\hline $\begin{array}{l}\text { Pombo; Luz; Rodrigues; Ferreira; } \\
\text { Cordovil, } 2020\end{array}$ & $\begin{array}{l}\text { COVID-19; Physical activity; Confinement } \\
\text { routines; Working from Home; Children }\end{array}$ & $\mathrm{x}$ & $x$ & $\mathrm{x}$ & & $\mathrm{x}$ & & $x$ & \\
\hline Power, Rogers, Kadi, 2020 & $\begin{array}{l}\text { Public Housing; COVID-19; Literature } \\
\text { Review }\end{array}$ & $x$ & $x$ & $x$ & & $\mathrm{x}$ & & & \\
\hline $\begin{array}{l}\text { Puplampu; Matthews; Puplampu; } \\
\text { Gross; Pathak; Peters, } 2019\end{array}$ & $\begin{array}{l}\text { Aging; Aging in place; Co-housing; Mixed } \\
\text { Methods; Older Adults; Quality of Life }\end{array}$ & & $x$ & & $x$ & $\mathrm{x}$ & & & \\
\hline Rodgers, 2020 & $\begin{array}{l}\text { Green Space; COVID-19; Planning Policy; } \\
\text { Urban Commons }\end{array}$ & $\mathrm{x}$ & & & & $\mathrm{x}$ & & $x$ & \\
\hline Shin, 2004 & $\begin{array}{l}\text { Co-housing; Life Satisfaction; Senior } \\
\text { Co-housing; Quality of Life }\end{array}$ & & $x$ & & $x$ & $\mathrm{x}$ & & & \\
\hline $\begin{array}{l}\text { Tokazhanov; Tleuken; Guney; } \\
\text { Turkyilmaz; Karaca, } 2020\end{array}$ & $\begin{array}{l}\text { COVID-19 Pandemic; Housing; Residential } \\
\text { Buildings; SARS-CoV-2; Sustainability } \\
\text { Requirements }\end{array}$ & $x$ & $x$ & $x$ & & $x$ & & & $\mathrm{x}$ \\
\hline Wang; Pan \& Hadjri, 2020 & $\begin{array}{l}\text { Co-housing; Motivations; Housing Decisions; } \\
\text { Social Sustainability; Environmental } \\
\text { Sustainability }\end{array}$ & & $x$ & & $x$ & $x$ & & & \\
\hline $\begin{array}{l}\text { Wang; Hadjri; Bennet; Morris, } \\
2020\end{array}$ & $\begin{array}{l}\text { Co-housing; Social Communication; } \\
\text { Sustainable Living environments; low carbon } \\
\text { lifestyle; affordable housing }\end{array}$ & & $x$ & & $x$ & $x$ & & & \\
\hline Boyraz \& Legros, 2020 & $\begin{array}{l}\text { Coronavirus Disease (COVID-19) Perceived } \\
\text { Vulnerability to COVID-19; } \\
\text { COVID-19-related Worries; Social Isolation } \\
\text { Traumatic Stress }\end{array}$ & $x$ & & $\mathrm{x}$ & & $x$ & $x$ & & \\
\hline
\end{tabular}


Table A1. Cont.

\begin{tabular}{|c|c|c|c|c|c|c|c|c|c|}
\hline \multirow{2}{*}{ Reference } & \multirow{2}{*}{ Keywords } & \multicolumn{8}{|c|}{ Main Topics } \\
\hline & & 1 & 2 & 3 & 4 & 5 & 6 & 7 & 8 \\
\hline Shim et al., 2020 & $\begin{array}{l}\text { Coronavirus; COVID-19; Korea; } \\
\text { Reproduction Number }\end{array}$ & $\mathrm{x}$ & & $\mathrm{x}$ & & & & & \\
\hline Saez et al., 2020 & $\begin{array}{l}\text { COVID-19 Mitigation; Physical Distancing; } \\
\text { Generalized Linear Mixed Models R-INLA }\end{array}$ & $\mathrm{x}$ & & $x$ & & & & & \\
\hline Holmes et al., 2020 & COVID-19; Mental Health; Physical Health & $\mathrm{x}$ & & $\mathrm{x}$ & & $\mathrm{x}$ & $\mathrm{x}$ & & \\
\hline Hawkley \& Cacioppo, 2010 & $\begin{array}{l}\text { Loneliness; Regulatory Loop; Physiology; } \\
\text { Health Behavior; Sleep; Intervention }\end{array}$ & & & & & $\mathrm{x}$ & $\mathrm{x}$ & & \\
\hline Casagrande et al., 2020 & $\begin{array}{l}\text { COVID-19; Generalized Anxiety } \\
\text { Psychological Well-being; Post-traumatic } \\
\text { Stress Disorder; PTSD; Sleep Quality }\end{array}$ & $\mathrm{x}$ & & $\mathrm{x}$ & & $\mathrm{x}$ & $\mathrm{x}$ & & \\
\hline Taylor et al., 2020 & $\begin{array}{l}\text { Anxiety; Coronavirus; COVID-19; Fear; } \\
\text { Pandemic; Stress; Xenophobia }\end{array}$ & $\mathrm{x}$ & & $x$ & & $\mathrm{x}$ & $x$ & & \\
\hline Park et al., 2020 & $\begin{array}{l}\text { Coronavirus; COVID-19; Optimistic Bias; } \\
\text { Perceived Risk; Risk Response; Health } \\
\text { Information; Seeking Attention; Behavioral } \\
\text { Outcomes }\end{array}$ & $\mathrm{x}$ & & $\mathrm{x}$ & & $\mathrm{x}$ & $\mathrm{x}$ & & \\
\hline Sanz-Barbero et al., 2018 & $\begin{array}{l}\text { Heat Wave; Intimate Partner Violence; } \\
\text { Femicides }\end{array}$ & & & & & $\mathrm{x}$ & $\mathrm{x}$ & & \\
\hline Baiano et al., 2020 & $\begin{array}{l}\text { Mental Health; Worry; Anxiety; Threat; } \\
\text { Mindfulness; COVID-19 }\end{array}$ & $\mathrm{x}$ & & $x$ & & $\mathrm{x}$ & $x$ & & \\
\hline Iglesias-Sánchez, 2020 & $\begin{array}{l}\text { Sentiment Analysis; Health Crisis; Isolation; } \\
\text { Confinement; Emergency Response; } \\
\text { Contagion of Emotions; COVID-19 }\end{array}$ & $\mathrm{x}$ & & $\mathrm{x}$ & & $\mathrm{x}$ & $\mathrm{x}$ & & \\
\hline Brooks et al., 2020 & $\begin{array}{l}\text { Sentiment Analysis; Health Crisis; Isolation; } \\
\text { Confinement; Emergency Response; } \\
\text { Contagion of Emotions; COVID-19 }\end{array}$ & $\mathrm{x}$ & & $\mathrm{x}$ & & $\mathrm{x}$ & $\mathrm{x}$ & & \\
\hline Kirwan, 2017 & $\begin{array}{l}\text { Insomnia; Anxiety; Emotion Regulation; } \\
\text { Non-Acceptance; Strategies }\end{array}$ & & & & & $\mathrm{x}$ & $x$ & & \\
\hline Torales et al., 2020 & $\begin{array}{l}\text { Outbreak; Coronavirus; Mental Health; } \\
\text { COVID-19 }\end{array}$ & $\mathrm{x}$ & & $\mathrm{x}$ & & $\mathrm{x}$ & $\mathrm{x}$ & & \\
\hline Choi et al., 2020 & $\begin{array}{l}\text { COVID-19; Depression; Anxiety; Mental } \\
\text { Health; Hong Kong }\end{array}$ & $\mathrm{x}$ & & $x$ & & $\mathrm{x}$ & $\mathrm{x}$ & & \\
\hline Zhang et al., 2020 & $\begin{array}{l}\text { Nature; Positive Emotions; Judgment of } \\
\text { Nature's Beauty; Generosity }\end{array}$ & $\mathrm{x}$ & & $\mathrm{x}$ & & $\mathrm{x}$ & $\mathrm{x}$ & & \\
\hline Fry-Bowers, 2020 & & $\mathrm{x}$ & & $\mathrm{x}$ & & $x$ & $\mathrm{x}$ & & \\
\hline García de Avila, 2020 & $\begin{array}{l}\text { Anxiety; Children; COVID-19; Pandemic; } \\
\text { Social Isolation }\end{array}$ & $\mathrm{x}$ & & $x$ & & $x$ & $x$ & & \\
\hline Fegert, 2020 & & $x$ & & $x$ & & $x$ & $\mathrm{x}$ & & \\
\hline Cao et al., 2020 & COVID-19; College Students; Psychological & $\mathrm{x}$ & & $\mathrm{x}$ & & $\mathrm{x}$ & $\mathrm{x}$ & & \\
\hline Somma et al., 2020 & $\begin{array}{l}\text { COVID-19 Pandemic; Emotional Problems; } \\
\text { Dysfunctional Personality Domains; } \\
\text { COVID-19; Causal Beliefs }\end{array}$ & $\mathrm{x}$ & & $\mathrm{x}$ & & $\mathrm{x}$ & $\mathrm{x}$ & & \\
\hline Reynolds et al., 2008 & & & & & & $\mathrm{x}$ & $\mathrm{x}$ & & \\
\hline Liu, 2020 & & $\mathrm{x}$ & & $\mathrm{x}$ & & $\mathrm{x}$ & $\mathrm{x}$ & & \\
\hline
\end{tabular}


Table A1. Cont.

\begin{tabular}{|c|c|c|c|c|c|c|c|c|c|}
\hline \multirow{2}{*}{ Reference } & \multirow{2}{*}{ Keywords } & \multicolumn{8}{|c|}{ Main Topics } \\
\hline & & 1 & 2 & 3 & 4 & 5 & 6 & 7 & 8 \\
\hline Lyu, 2012 & $\begin{array}{l}\text { Public Health Crises; Traditional Media } \\
\text { Dependency; Internet Dependency; } \\
\text { Perception of Threat; Mainland China }\end{array}$ & & & & & $x$ & $x$ & & \\
\hline Amerio et al., 2020 & $\begin{array}{l}\text { COVID-19; Lockdown; Housing Built } \\
\text { Environment; Mental Health; Evidence-based } \\
\text { Design }\end{array}$ & & & & & $x$ & $x$ & $x$ & \\
\hline Heintzman, 2009 & $\begin{array}{l}\text { Nature; Outdoor Recreation; Spirituality; } \\
\text { Research; Theory }\end{array}$ & & & & & $x$ & $\mathrm{x}$ & $\mathrm{x}$ & \\
\hline Zhang et al., 2014 & $\begin{array}{l}\text { Coronavirus; Mental Health; Sleep Quality; } \\
\text { Physical Activity; Mitigation Strategies }\end{array}$ & & & & & $x$ & $x$ & $\mathrm{x}$ & \\
\hline Chawla, 2015 & $\begin{array}{l}\text { Health; Recreation and Open Space; Urban } \\
\text { Design; Neighborhood Planning; Children; } \\
\text { Adolescents }\end{array}$ & & & & & $x$ & $x$ & $\mathrm{x}$ & \\
\hline Clayton et al., 2016 & $\begin{array}{l}\text { Conservation; Biodiversity; Attitudes; Values; } \\
\text { Social Context; Experience of Nature }\end{array}$ & & & & & $\mathrm{x}$ & $x$ & $\mathrm{x}$ & \\
\hline Ebrahimpour, 2020 & $\begin{array}{l}\text { Biophilic Design; Hot and Dry Climate } \\
\text { Biophilic Indicators; Meta-Synthesis } \\
\text { Research; Nvivo Software }\end{array}$ & & & & & $\mathrm{x}$ & $\mathrm{x}$ & $\mathrm{x}$ & \\
\hline Brambilla et al., 2019 & $\begin{array}{l}\text { Built Environment; Evidence Based Design; } \\
\text { Fall Reduction; Hospital; Job Satisfaction; } \\
\text { Patient Satisfaction; Quality }\end{array}$ & & & & & $\mathrm{x}$ & $\mathrm{x}$ & & $\mathrm{x}$ \\
\hline Amerio et al., 2020 & $\begin{array}{l}\text { COVID-19; Lockdown; Housing Built } \\
\text { Environment; Mental Health; } \\
\text { Evidence-Based Design }\end{array}$ & $\mathrm{x}$ & $\mathrm{x}$ & $\mathrm{x}$ & & $\mathrm{x}$ & $\mathrm{x}$ & & \\
\hline
\end{tabular}

\section{Appendix B}

This appendix aims to present the mathematical results of the survey, gathered by demographic characteristics and contexts.

Table A2. Results of the survey analyzed with participants' gender.

\begin{tabular}{|c|c|c|c|c|c|}
\hline & Female & Male & NB * & PNTS & TOTAL \\
\hline & 100 & 43 & $1(\%)$ & 3 & 147 \\
\hline 8-How much has your way of socializing changed? & $3.24(2.04)$ & $4.09(2.31)$ & 3.00 & $5.67(2.31)$ & $3.54(2.16)$ \\
\hline $\begin{array}{l}\text { 9-How much has the way to meet other community } \\
\text { members changed? }\end{array}$ & $3.18(1.98)$ & $3.69(2.27)$ & 3.00 & $2.33(0.58)$ & $3.31(2.05)$ \\
\hline $\begin{array}{l}\text { 10-How much have the open-air activities within the } \\
\text { community changed? }\end{array}$ & $5.92(2.86)$ & $5.63(2.20)$ & 4.00 & $5.67(1.15)$ & $5.82(2.64)$ \\
\hline $\begin{array}{l}\text { 11-Have you suffered because of the (eventual) lack } \\
\text { of social relations within the community? }\end{array}$ & $4.93(2.79)$ & $3.83(2.76)$ & 1.00 & $2.33(1.15)$ & $4.53(2.81)$ \\
\hline $\begin{array}{l}\text { 12-Have you suffered because of the (eventual) lack } \\
\text { of social relations outside the community? }\end{array}$ & $6.27(2.66)$ & $5.16(2.60)$ & 1.00 & $3.33(2.31)$ & $5.85(2.71)$ \\
\hline $\begin{array}{l}\text { 13-Facing the emergency, do you think you have } \\
\text { been luckier or not, compared with people living in } \\
\text { traditional housing? }\end{array}$ & $9.01(1.80)$ & $7.72(2.23)$ & 8.00 & $9.33(0.58)$ & $8.63(2.00)$ \\
\hline $\begin{array}{l}\text { 14-Do you think the way in which the community is } \\
\text { using the COMMON spaces has changed? }\end{array}$ & $9.24(2.10)$ & $8.58(2.30)$ & 9.00 & $10.00(0.00)$ & $9.06(2.15)$ \\
\hline 15-Are you still using the shared space? & $2.13(2.47)$ & $3.00(2.92)$ & 1.00 & $0.67(1.15)$ & $2.35(2.61)$ \\
\hline 16-Are you still using the open-air shared space? & $6.98(3.03)$ & $6.81(2.75)$ & 4.00 & $8.00(1.73)$ & $6.93(2.92)$ \\
\hline $\begin{array}{l}\text { 17-Do you think living in co-housing has made it } \\
\text { easier to face the contingency? }\end{array}$ & 8.57 (2.19) & $7.77(2.11)$ & 6.00 & $9.33(0.58)$ & $8.33(2.17)$ \\
\hline
\end{tabular}


Table A3. Results of the survey analyzed with participants' age.

\begin{tabular}{|c|c|c|c|c|c|c|c|c|}
\hline & $18-30$ & $31-40$ & $41-50$ & $51-60$ & $61-70$ & $70+$ & PNTS & TOTAL \\
\hline & 2 & 6 & 14 & 27 & 56 & $41(\%)$ & 1 & 147 \\
\hline $\begin{array}{l}\text { 8-How much has your way of } \\
\text { socializing changed? }\end{array}$ & $\begin{array}{c}3.00 \\
(1.41)\end{array}$ & $\begin{array}{c}4.33 \\
(2.58)\end{array}$ & $\begin{array}{c}3.00 \\
(2.42)\end{array}$ & $\begin{array}{c}3.85 \\
(2.14)\end{array}$ & $\begin{array}{c}3.61 \\
(2.28)\end{array}$ & $\begin{array}{c}3.34 \\
(1.96)\end{array}$ & 5.00 & $\begin{array}{c}3.54 \\
(2.16)\end{array}$ \\
\hline $\begin{array}{l}\text { 9-How much has the way to meet other } \\
\text { community members changed? }\end{array}$ & $\begin{array}{c}2.00 \\
(1.41)\end{array}$ & $\begin{array}{c}5.50 \\
(3.62)\end{array}$ & $\begin{array}{c}2.43 \\
(1.09)\end{array}$ & $\begin{array}{c}3.33 \\
(1.86)\end{array}$ & $\begin{array}{c}3.55 \\
(2.27)\end{array}$ & $\begin{array}{c}3.02 \\
(1.65)\end{array}$ & 3.00 & $\begin{array}{c}3.31 \\
(2.05)\end{array}$ \\
\hline $\begin{array}{l}\text { 10-How much has the open-air activities } \\
\text { within the community changed? }\end{array}$ & $\begin{array}{c}2.00 \\
(1.41)\end{array}$ & $\begin{array}{c}7.17 \\
(1.83)\end{array}$ & $\begin{array}{c}5.50 \\
(3.32)\end{array}$ & $\begin{array}{c}6.52 \\
(2.19)\end{array}$ & $\begin{array}{l}5.73 \\
(2.75)\end{array}$ & $\begin{array}{l}5.54 \\
(2.53)\end{array}$ & 7.00 & $\begin{array}{l}5.82 \\
(2.64)\end{array}$ \\
\hline $\begin{array}{l}\text { 11-Did you suffer because of the } \\
\text { (eventual) lack of social relations within } \\
\text { the community? }\end{array}$ & $\begin{array}{c}6.00 \\
(1.41)\end{array}$ & $\begin{array}{c}4.00 \\
(3.03)\end{array}$ & $\begin{array}{l}5.36 \\
(2.84)\end{array}$ & $\begin{array}{c}4.15 \\
(3.00)\end{array}$ & $\begin{array}{l}4.18 \\
(2.94)\end{array}$ & $\begin{array}{c}5.07 \\
(2.45)\end{array}$ & 1.00 & $\begin{array}{l}4.53 \\
(2.81)\end{array}$ \\
\hline $\begin{array}{l}\text { 12-Did you suffer because of the } \\
\text { (eventual) lack of social relations outside } \\
\text { the community? }\end{array}$ & $\begin{array}{c}7.00 \\
(2.83)\end{array}$ & $\begin{array}{c}6.67 \\
(2.73)\end{array}$ & $\begin{array}{c}6.57 \\
(2.17)\end{array}$ & $\begin{array}{l}5.26 \\
(3.17)\end{array}$ & $\begin{array}{l}5.27 \\
(2.70)\end{array}$ & $\begin{array}{c}6.63 \\
(2.45)\end{array}$ & 6.00 & $\begin{array}{l}5.85 \\
(2.71)\end{array}$ \\
\hline $\begin{array}{l}\text { 13-Facing the emergency, do you think } \\
\text { you have been luckier or not, compared } \\
\text { with people living in traditional housing? }\end{array}$ & $\begin{array}{c}6.00 \\
(4.24)\end{array}$ & $\begin{array}{c}8.83 \\
(1.17)\end{array}$ & $\begin{array}{c}7.86 \\
(2.54)\end{array}$ & $\begin{array}{c}9.19 \\
(1.39)\end{array}$ & $\begin{array}{l}8.68 \\
(2.00)\end{array}$ & $\begin{array}{c}8.54 \\
(2.06)\end{array}$ & 10.00 & $\begin{array}{l}8.63 \\
(2.00)\end{array}$ \\
\hline $\begin{array}{l}\text { 14-Do you think the way in which the } \\
\text { community is using the COMMON } \\
\text { spaces has changed? }\end{array}$ & $\begin{array}{l}10.00 \\
(0.00)\end{array}$ & $\begin{array}{l}10.00 \\
(0.00)\end{array}$ & $\begin{array}{c}9.50 \\
(1.34)\end{array}$ & $\begin{array}{c}8.81 \\
(2.56)\end{array}$ & $\begin{array}{c}9.27 \\
(1.65)\end{array}$ & $\begin{array}{c}8.61 \\
(2.75)\end{array}$ & 10.00 & $\begin{array}{c}9.06 \\
(2.15)\end{array}$ \\
\hline 15-Are you still using the shared space? & $\begin{array}{c}0.50 \\
(0.71)\end{array}$ & $\begin{array}{c}2.40 \\
(1.14)\end{array}$ & $\begin{array}{l}(1.43) \\
2.62\end{array}$ & $\begin{array}{c}3.30 \\
(3.18)\end{array}$ & $\begin{array}{c}2.41 \\
(2.59)\end{array}$ & $\begin{array}{c}2.05 \\
(2.32)\end{array}$ & 2.00 & $\begin{array}{c}2.35 \\
(2.61)\end{array}$ \\
\hline $\begin{array}{l}\text { 16-Are you still using the open-air } \\
\text { shared space? }\end{array}$ & $\begin{array}{c}3.50 \\
(4.95)\end{array}$ & $\begin{array}{c}7.40 \\
(2.88)\end{array}$ & $\begin{array}{c}6.14 \\
(4.00)\end{array}$ & $\begin{array}{l}7.26 \\
(2.64)\end{array}$ & $\begin{array}{l}7.00 \\
(2.87)\end{array}$ & $\begin{array}{c}6.93 \\
(2.71)\end{array}$ & 10.00 & $\begin{array}{c}6.93 \\
(2.92)\end{array}$ \\
\hline $\begin{array}{l}\text { 17-Do you think living in co-housing has } \\
\text { made it easier to face the contingency? }\end{array}$ & $\begin{array}{c}5.50 \\
(4.95)\end{array}$ & $\begin{array}{r}7.67 \\
(2.07)\end{array}$ & $\begin{array}{c}6.64 \\
(3.67)\end{array}$ & $\begin{array}{c}8.56 \\
(1.55)\end{array}$ & $\begin{array}{c}8.54 \\
(2.15)\end{array}$ & $\begin{array}{c}8.68 \\
(1.44)\end{array}$ & 10.00 & $\begin{array}{l}8.33 \\
(2.17)\end{array}$ \\
\hline
\end{tabular}

\section{References}

1. Abebaw Mengistu, Y. COPD patients in a COVID-19 society: Depression and anxiety. Expert Rev. Respir. Med. 2020, 15, 5-7.

2. Franch-Pardo, I.; Napoletano, V.; Rosete-Verges, F.; Billa, L. Spatial analysis and GIS in the study of COVID-19. A review. Sci. Total Environ. 2020, 739, 140033. [CrossRef] [PubMed]

3. Barrot, J.; Grassi, B.; Sauvagnat, J. Costs and Benefits of Closing Businesses in a Pandemic. SSRN 2020, 1-50. Available online: https:/ / papers.ssrn.com/sol3/papers.cfm?abstract_id=3599482, (accessed on 24 February 2021).

4. Gumel, A.B.; Iboi, E.A.; Ngonghala, C.N.; Elbasha, E.H. A primer on using mathematics to understand COVID-19 dynamics: Modeling, analysis and simulations. Infect. Dis. Model. 2021, 6, 148-168. [CrossRef]

5. Singh, Jaspreet and Singh, Jagandeep, COVID-19 and Its Impact on Society. Electron. Res. J. Soc. Sci. Humanit. 2020, 2. Available online: https: / / ssrn.com/abstract=3567837 (accessed on 3 April 2020).

6. Holmes, E.A.; O'Connor, R.C.; Perry, V.H.; Tracey, I.; Wessely, S.; Arseneault, L.; Ballard, C.; Christensen, H.; Silver, R.C.; Everall, I.; et al. Multidisciplinary research priorities for the COVID-19 pandemic: A call for action for mental health science. Lancet Psychiatry 2020, 7, 547-560. [CrossRef]

7. Baiano, C.; Zappullo, I.; Conson, M. Tendency to Worry and Fear of Mental Health during Italy's COVID-19 Lockdown. Int. J. Environ. Res. Public Health 2020, 17, 5928. [CrossRef] [PubMed]

8. Serafini, G.; Parmigiani, B.; Amerio, A.; Aguglia, A.; Sher, L.; Amore, M. The psychological impact of COVID-19 on the mental health in the general population. QJM 2020, 113, 531-537. [CrossRef] [PubMed]

9. Torales, J.; O'Higgins, M.; Castaldelli-Maia, J.M.; Ventriglio, A. The outbreak of COVID-19 coronavirus and its impact on global mental health. Int. J. Soc. Psychiatry 2020, 66, 317-320. [CrossRef]

10. Allam, Z.; Jones, D.S. On the Coronavirus (COVID-19) Outbreak and the Smart City Network: Universal Data Sharing Standards Coupled with Artificial Intelligence (AI) to Benefit Urban Health Monitoring and Management. Healthcare 2020, 8, 46. [CrossRef]

11. EQUIDE. La Ibero Presenta la Encuesta de Seguimiento de los Efectos del Covid en el Bienestar de los Hogares Mexicanos \#Encovid. Available online: https://ibero.mx/sites/default/files/comunicado_encovid-19_completo.pdf (accessed on 14 March 2021).

12. Ziccardi, A. Las grandes regiones urbanas y el distanciamiento social impuesto por el COVID-19. Astrolabio 2020, $25,46-64$.

13. Hou, C.; Chen, J.; Zhou, Y.; Hua, L.; Yuan, J.; He, S.; Guo, Y.; Zhang, S.; Jia, Q.; Zhao, C.; et al. The effectiveness of the quarantine of Wuhan city against the Corona Virus Disease 2019 (COVID-19): Well-mixed SEIR model analysis. J. Med. Virol. 2019, 92, 841-848. [CrossRef] [PubMed] 
14. Ferguson, N.M.; Laydon, D.; Nedjati-Gilani, G.; Imai, N.; Ainslie, K.; Baguelin, M.; Bhatia, S.; Boonyasiri, A.; Cucunubá, Z.; Cuomo-Dannenburg, G.; et al. Impact of Non-Pharmaceutical Interventions (NPIs) to Reduce COVID-19 Mortality and Healthcare Demand; Imperial College London: London, UK, 2020. [CrossRef]

15. Boyraz, G.; Legros, D.N. Coronavirus disease (COVID-19) and traumatic stress: Probable risk factors and correlates of posttraumatic stress disorder. J. Loss Trauma 2020, 25, 503-522. [CrossRef]

16. Shim, E.; Tariq, A.; Choi, W.; Lee, Y.; Chowell, G. Transmission potential and severity of COVID-19 in South Korea. Int. J. Infect. Dis. 2020, 93, 339-344. [CrossRef]

17. Saez, M.; Tobias, A.; Varga, D.; Barcelo, M.A. Effectiveness of the measures to flatten the epidemic curve of COVID-19. The case of Spain. Sci. Total Environ. 2020, 727, 138761. [CrossRef]

18. OECD. Supporting the Continuation of Teaching and Learning during the COVID-19 Pandemic Annotated Resources for Online Learning; OECD: Paris, France, 2020.

19. Greenstone, M.; Nigam, V. Does Social Distancing Matter? Working Paper No. 2020-26; University of Chicago, Becker Friedman Institute for Economics: Chicago, IL, USA, 2020.

20. Xu, J.; Ou, J.; Luo, S.; Wang, Z.; Chang, E.; Novak, C.; Shen, J.; Zheng, S.; Wang, Y. Perceived Social Support Protects Lonely People Against COVID-19 Anxiety: A Three-Wave Longitudinal Study in China. Front. Psychol. 2020, 11, 566965. [CrossRef] [PubMed]

21. Hawkley, L.C.; Cacioppo, J.T. Loneliness matters: A theoretical and empirical review of consequences and mechanisms. Ann. Behav. Med. A Publ. Soc. Behav. Med. 2010, 40, 218-227. [CrossRef] [PubMed]

22. Casagrande, M.; Favieri, F.; Tambelli, R.; Forte, G. The enemy who sealed the world: Effects quarantine due to the COVID-19 on sleep quality, anxiety, and psychological distress in the Italian population. Sleep Med. 2020, 75, 12-20. [CrossRef]

23. Taylor, S.; Landry, C.A.; Paluszek, M.M.; Fergus, T.A.; McKay, D.; Asmundson, G.J.G. Development and initial validation of the COVID stress scales. J. Anxiety Disord. 2020, 72, 102232. [CrossRef]

24. Taylor, S.; Landry, C.A.; Paluszek, M.M.; Fergus, T.A.; McKay, D.; Asmundson, G.J.G. COVID stress syndrome: Concept, structure, and correlates. Depress. Anxiety 2020, 37, 706-714. [CrossRef]

25. Sun, L.; Sun, Z.; Wu, L.; Zhu, Z.; Zhang, F.; Shang, Z.; Jia, Y.; Gu, J.; Zhou, Y.; Wang, Y.; et al. Prevalence and risk factors of acute posttraumatic stress symptoms during the COVID-19 outbreak in Wuhan, China. J. Affect. Disord. 2020, 283, 123-129. [CrossRef]

26. Park, T.; Ju, I.; Ohs, J.E.; Hinsley, A. Optimistic bias and preventive behavioral engagement in the context of COVID-19. Res. Soc. Adm. Pharm. 2020, 17, 1859-1866. [CrossRef] [PubMed]

27. Miller, S.L.; Maner, J.K. Overperceiving disease cues: The basic cognition of the behavioral immune system. J. Personal. Soc. Psychol. 2012, 102, 1198-1213. [CrossRef]

28. Ozer, E.J.; Best, S.R.; Lipsey, T.L.; Weiss, D.S. Predictors of posttraumatic stress disorder and symptoms in adults: A meta-analysis. Psychol. Bull. 2003, 129, 52-73. [CrossRef] [PubMed]

29. Tolin, D.F.; Foa, E.B. Sex differences in trauma and posttraumatic stress disorder: A quantitative review of 25 years of research Psychol. Bull. 2006, 132, 959-992. [CrossRef]

30. Brewin, C.R.; Andrews, B.; Valentine, J.D. Meta-analysis of risk factors for posttraumatic stress disorder in trauma-exposed adults. J. Consult. Clin. Psychol. 2000, 68, 748-766. [CrossRef] [PubMed]

31. Wagers, S. Domestic Violence Growing in the Wake of Coronavirus Outbreak. The Conversation. Available online: https: / / theconversation.com/domestic-violence-growing-in-wake-of-coronavirus-outbreak-135598 (accessed on 11 April 2020).

32. Taub, A. A New COVID-19 Crisis: Domestic Abuse Rises Worldwide. New York Times. Available online: https://www.nytimes. com/2020/04/06/world/coronavirus-domestic-violence.html (accessed on 13 April 2020).

33. Sanz-Barbero, B.; Linares, C.; Vives-Cases, C.; González, J.L.; López-Ossorio, J.J.; Díaz, J. Heat wave and the risk of intimate partner violence. Sci. Total Environ. 2018, 644, 413-419. [CrossRef] [PubMed]

34. Brooks, S.K.; Webster, R.K.; Smith, L.E.; Woodland, L.; Wessely, S.; Greenberg, N.; Rubin, G.J. The psychological impact of quarantine and how to reduce it: Rapid review of the evidence. Lancet 2020, 395, 912-920. [CrossRef]

35. Na, K.; Garrett, R.K.; Slater, M.D. Rumor Acceptance during Public Health Crises: Testing the Emotional Congruence Hypothesis. J. Health Commun. 2018, 23, 791-799. [CrossRef]

36. Iglesias-Sánchez, P.P.; Vaccaro Witt, G.F.; Cabrera, F.E.; Jambrino-Maldonado, C. The Contagion of Sentiments during the COVID-19 Pandemic Crisis: The Case of Isolation in Spain. Int. J. Environ. Res. Public Health 2020, 17, 5918. [CrossRef] [PubMed]

37. Kirwan, M.; Pickett, S.M.; Jarrett, N.L. Emotion regulation as a moderator between anxiety symptoms and insomnia symptom severity. Psychiatry Res. 2017, 254, 40-47. [CrossRef] [PubMed]

38. Choi, E.P.H.; Hui, B.P.H.; Wan, E.Y.F. Depression and anxiety in Hong Kong during COVID-19. Int. J. Environ. Res. Public Health 2020, 17, 3740. [CrossRef]

39. Zhang, Y.; Zhang, H.; Ma, X.; Di, Q. Mental health problems during the COVID-19 pandemics and the mitigation e_ects of exercise: A longitudinal study of college students in China. Int. J. Environ. Res. Public Health 2020, 17, 3722. [CrossRef] [PubMed]

40. Rashidi Fakari, F.; Simbar, M. Coronavirus Pandemic and Worries during Pregnancy; a Letter to Editor. Arch. Acad. Emerg. Med. 2020, 8, e21.

41. Evenson, K.R.; Savitz, D.A.; Huston, S.L. Leisure-time physical activity among pregnant women in the US. Paediatr. Perinat. Epidemiol. 2004, 18, 400-407. [CrossRef] [PubMed]

42. Fry-Bowers, E.K. Children are at risk from COVID-19. J. Pediatr. Nurs. 2020, 53, A10-A12. [CrossRef] [PubMed] 
43. De Garcia Avila, M.A.; Hamamoto Filho, P.T.; Jacob, F.L.; Alcantara, L.R.; Berghammer, M.; Jenholt Nolbris, M.; Olaya-Contreras, P.; Nilsson, S. Children's Anxiety and Factors Related to the COVID-19 Pandemic: An Exploratory Study Using the Children's Anxiety Questionnaire and the Numerical Rating Scale. Int. J. Environ. Res. Public Health 2020, 17, 5757. [CrossRef]

44. Fegert, J.M.; Vitiello, B.; Plener, P.L.; Clemens, V. Challenges and burden of the coronavirus 2019 (COVID-19) pandemic for child and adolescent mental health: A narrative review to highlight clinical and research needs in the acute phase and the long return to normality. Child Adolesc. Psychiatry Ment. Health 2020, 14, 20. [CrossRef]

45. Cao, W.; Fang, Z.; Hou, G.; Han, M.; Xu, X.; Dong, J.; Zheng, J. The psychological impact of the COVID-19 epidemic on college students in China. Psychiatry Res. 2020, 287, 112934. [CrossRef]

46. Somma, A.; Gialdi, G.; Krueger, R.F.; Markon, K.E.; Frau, C.; Lovallo, S.; Fossati, A. Dysfunctional personality features, nonscientifically supported causal beliefs, and emotional problems during the first month of the COVID-19 pandemic in Italy. Pers. Individ. Dif. 2020, 165, 110139. [CrossRef] [PubMed]

47. Reynolds, D.; Garay, J.; Deamond, S.; Moran, M.; Gold, W.; Styra, R. Understanding, compliance and psychological impact of the SARS quarantine experience. Epidemiol. Infect. 2008, 136, 997-1007. [CrossRef]

48. Liu, J.J.; Bao, Y.; Huang, X.; Shi, J.; Lu, L. Mental health considerations for children quarantined because of COVID-19. Lancet Child Adolesc. Health 2020, 4, 347-349. [CrossRef]

49. Gruzd, A.; Doiron, S.; Mai, P. Is Happiness Contagious Online? A Case of Twitter and the 2010 Winter Olympics. In Proceedings of the 2011 44th Hawaii International Conference on System Sciences, Kauai, HI, USA, 4-7 January 2011; pp. 1-9.

50. Lyu, J.C. How young Chinese depend on the media during public health crises? A comparative perspective. Public Relat. Rev. 2012, 38, 799-806. [CrossRef]

51. Davies, W. The Last Global Crisis Didn't Change the World. But This One Could. The Guardian. Available online: https: //www.theguardian.com (accessed on 24 March 2020).

52. Rogers, D.; Power, E. Housing policy and the COVID-19 pandemic: The importance of housing research during this health emergency. Int. J. Hous. Policy 2020, 20, 177-183. [CrossRef]

53. Brunetta, G.; Moroni, S. La Città Intraprendente, Comunità Contrattuali e Sussidiarietà Orizzontale; Carocci Editore: Rome, Italy, 2011.

54. Guidotti, F. Ecovillaggi e Cohousing. Dove Sono, Chi li Anima, Come Farne Parte o Realizzarne di Nuovi; Terra Nuova Edizioni: Cesena, Italy, 2013.

55. Giorgi, E. The Co-Housing Phenomenon. Environmental Alliance in Times of Changes; Springer Nature: Cham, Switzerland, 2020.

56. Sfriso, S. Dire, fare ... coabitare. In L'abitare Condiviso: Le Residenze Collettive Dalle Origini al Cohousing; Narne, E., Sfriso, S., Eds.; Marsilio: Venezia, Italy, 2013; pp. 43-59.

57. McCamant, K.; Durrett, C. Cohousing: A Contemporary Approach to Housing Ourselves; Ten Speed Press: Berkeley, CA, USA, 2004.

58. Lietaert, M. Il cohousing: Origini, storia ed evoluzione in Europa e nel mondo. In Famiglie, Reti Famigliari e Cohousing; Sapio, A., Ed.; Franco Angeli Editore: Milano, Italy, 2010; pp. 140-148.

59. Vestbro, D.U.; Horelli, L. Design for gender equality-The history of cohousing ideas and realities. Built Environ. 2012, 38, 315-335. [CrossRef]

60. Muxí, Z. Mujeres, Casas y Ciudades: Más Allá del Umbral; DPR: Barcelona, Spain, 2018; p. 61.

61. Kaplan, R.; Kaplan, S. The Experience of Nature: A Psychological Perspective; Cambridge University Press: New York, NY, USA, 1989.

62. Ulrich, R.S.; Simons, R.F.; Losito, B.D.; Fiorito, E.; Miles, M.A.; Zelson, M. Stress recovery during exposure to natural and urban environments. J. Environ. Psychol. 1991, 11, 201-230. [CrossRef]

63. Amerio, A.; Brambilla, A.; Morganti, A.; Aguglia, A.; Bianchi, D.; Santi, F.; Costantini, L.; Odone, A.; Costanza, A.; Signorelli, C.; et al. COVID-19 Lockdown: Housing Built Environment's Effects on Mental Health. Int. J. Environ. Res. Public Health 2020, 17, 5973. [CrossRef] [PubMed]

64. White, M.P.; Alcock, I.; Grellier, J.; Wheeler, B.W.; Hartig, T.; Warber, S.L.; Bone, A.; Depledge, M.H.; Fleming, L.E. Spending at least 120 minutes a week in nature is associated with good health and wellbeing. Sci. Rep. 2019, 9, 7730. [CrossRef]

65. Corraliza, J.A.; Berenguer, J.; Martín, R. Medio Ambiente, Bienestar Humano y Responsabilidad Ecológica; Editorial Resma: Madrid, Spain, 2006.

66. Heintzman, P. Nature-Based Recreation and Spirituality: A Complex Relationship. Leis. Sci. 2009, 32, 72-89. [CrossRef]

67. Zhang, J.W.; Piff, P.K.; Iyer, R.; Koleva, S.; Keltner, D. An occasion for unselfing: Beautiful nature leads to prosociality. J. Environ. Psychol. 2014, 37, 61-72. [CrossRef]

68. Chawla, L. Benefits of Nature Contact for Children. J. Plan. Lit. 2015, 30, 433-452. [CrossRef]

69. Clayton, S.; Colleony, A.; Conversy, P.; Maclouf, E.; Martin, L.; Torres, A.C.; Truong, M.X.; Prevot, A.C. Transformation of experience: Toward a new relationship with nature. Conserv. Lett. 2016, 10, 645-651. [CrossRef]

70. Johnson, N. Why Biophilic Architecture Works: Five Reasons and Case Studies. Available online: https://www. architectureanddesign.com.au/features/features-articles/why-biophilic-architecture-works-five-reasons-and (accessed on 30 September 2014).

71. Ebrahimpour, M. Proposing a framework of biophilic design principles in hot and arid climate of Iran by using grounded theory. CEE 2020, 16, 71-78. [CrossRef]

72. Ortega Andeane, P.; Estrada, C.; Toledano, F.; Campos, J. Calidad ambiental, carga y estrés en cuidadores primarios informales de un hospital pediátrico. In Ambientes Hospitalarios y Estrés; Ortega, P., Estrada, C., Eds.; Facultad de Psicología UNAM: Mexico City, Mexico, 2018; pp. 65-96. 
73. Ulrich, R.S.; Zimring, C.; Zhu, X.; DuBose, J.; Seo, H.B.; Choi, Y.S.; Quan, X.; Joseph, A.A. Review of the research literature on evidence-based healthcare design. Health Environ. Res. Des. J. 2008, 1, 61-125. [CrossRef] [PubMed]

74. Brambilla, A.; Rebecchi, A.; Capolongo, S. Evidence based hospital design. A literature review of the recent publications about the EBD impact of built environment on hospital occupants' and organizational outcomes. Ann. Ig. 2019, 31, 165-180. [PubMed]

75. Garber, M. Homes Actually Need to Be Practical Now: One of the Ironies of Social Distancing Is That It Can Put Privacy in Short Supply. The Atlantic. Available online: https://www.theatlantic.com/culture/archive/2020/03/finding-privacy-duringpandemic/608944/ (accessed on 11 April 2020).

76. Rubin, G.J.; Wessely, S. The psychological effects of quarantining a city. BMJ 2020, 368, m313. [CrossRef]

77. Stokols, D. The changing morphology of indoor ecosystems in the twenty-first century driven by technological, climatic, and sociodemographic forces. Hum. Ecol. Rev. 2018, 24, 25-40. [CrossRef]

78. Crisanti, A.S.; Duran, D.; Greene, R.N.; Reno, J.; Luna-Anderson, C.; Altschul, D.B. A longitudinal analysis of peer-delivered permanent supportive housing: Impact of housing on mental and overall health in an ethnically diverse population. Psychol. Serv. 2017, 14, 141-153. [CrossRef]

79. Ahmad, K.; Erqou, S.; Shah, N.; Nazir, U.; Morrison, A.; Choudhary, G.; Wu, W. Association of poor housing conditions with COVID-19 incidence and mortality across US counties. PLoS ONE 2020, 15, e0241327. [CrossRef]

80. UNSD. Informe Sobre los Objetivos de Desarrollo Sostenible 2019. División de Estadística de las Naciones Unidas. Available online: https:/ / unstats.un.org/sdgs/report/2019/ (accessed on 13 April 2020).

81. Azzopardi-Muscat, N.; Brambilla, A.; Caracci, F.; Capolongo, S. Synergies in design and health. The role of architects and urban health planners in tackling key contemporary public health challenges. Acta Biomed. 2020, 91, 9-20.

82. Signorelli, C.; Capolongo, S.; D'Alessandro, D.; Fara, G.M. The homes in the COVID-19 era. How their use and values are changing. Acta Biomed 2020, 91 (Suppl. 9), 92-94.

83. Groat, L.N.; Wang, D. Architectural Research Methods, 2nd ed.; Wiley: Hoboken, NJ, USA, 2013; pp. $280-292$.

84. Mertens, D. Research Methods in Education and Psychology; SAGE Publications: Thousand Oaks, CA, USA, 1998 ; pp. $115-117$.

85. Cohousing. Available online: https://www.cohousing.org/directory/ (accessed on 15 April 2020).

86. Smith, W.G. Does Gender Influence Online Survey Participation? A Rec-ord-Linkage Analysis of University Faculty Online Survey Response Behavior. Available online: https: / / eric.ed.gov/?id=ED501717 (accessed on 9 March 2021).

87. Underwood, D.; Kim, H.; Matier, M. To mail or to Web: Comparisons of survey response rates and respondent characteristics. In Proceedings of the 40th Annual Forum of the Association for Institutional Research, Cincinnati, OH, USA, $21-24$ May 2000. 